УДК 316.444::378.14(4)

Стрюк Микола Іванович

доцент, кандидат історичних наук, проректор з науково-педагогічної та навчально-виховної роботи Державний вищий навчальний заклад «Криворізький національний університет», м. Кривий Ріг, Україна stryukm@gmail.com

Семеріков Сергій Олексійович

професор, доктор педагогічних наук,

завідувач кафедри фундаментальних і соціально-гуманітарних дисциплін

Державний вищий навчальний заклад «Криворізький національний університет», м. Кривий Ріг, Україна semerikov@gmail.com

Стрюк Андрій Миколайович

доцент, кандидат педагогічних наук, докторант

Інститут інформаційних технологій і засобів навчання НАПН України, м. Київ, Україна

andrey.n.stryuk@gmail.com

\title{
МОБІЛЬНІСТЬ: СИСТЕМНИЙ ПІДХІД
}

\begin{abstract}
Анотація. У статті проведено комплексне дослідження проблеми мобільності у соціальнопедагогічних і технічних системах: проаналізовано еволюцію поняття мобільності у наукових джерелах XIX-XXI століть й уведено в науковий обіг нові першоджерела 3 проблеми мобільності, теоретично обгрунтовано співвідношення видів мобільності в соціально-педагогічних i технічних системах, запропоновано інтегративну модель мобільності в інформаційному суспільстві. Виокремлено основні тенденції розвитку академічної мобільності (перехід від мобільності студентів до мобільності програм i постачальників освітніх послуг) й охарактеризовано нові програми мобільності (франчайзінг, подвійні/спільні ступені, поєднання, нострифікація тощо). Розглянуто нові види постачальників мобільності й акцентовано увагу на віртуальних університетах, що $\epsilon$ нині основою віртуальної мобільності студентів і діяльність яких базуються на використанні нових ІКТ у вищій освіті, насамперед - Інтернет і мобільних навчальних середовищ.
\end{abstract}

Ключові слова: реальна мобільність; віртуальна мобільність; географічна мобільність; соціальна мобільність; професійна мобільність; академічна мобільність; навчальна мобільність; програмна мобільність; апаратна мобільність; технологічна мобільність; мобільні комунікації; мобільне суспільство; інформаційне суспільство.

\section{1. ВСТУП}

Постановка проблеми. «Національна стратегія розвитку освіти в Україні на період до 2021 року» [93] визначає напрями перебудови вітчизняної системи освіти у зв'язку з необхідністю іiі інтеграції в європейський і світовий освітній простори, переходом до постіндустріальної цивілізації, чим має забезпечитись сталий розвиток України в першій половині XXI століття. Удосконалення структури вітчизняної системи освіти передбачає приведення структури і змісту вищої освіти у відповідність до європейських стандартів, урізноманітнення моделей організації освіти, задоволення освітніх інформаційних і комунікаційних потреб учасників навчально-виховного процесу на основі прогнозування тенденцій інноваційного розвитку системи освіти 3 використанням результатів порівняльно-педагогічних досліджень.

Європейська Комісія підтримує модернізацію національних систем вищої освіти за такими напрямами:

1) розробка національних стратегій розвитку вищої освіти, спрямованих на: збільшення кількості випускників ВНЗ, підвищення їх конкурентоспроможності, надання студентам можливості мобільного навчання у європейському просторі вищої 
освіти (СПВО), посилення «трикутника знань» (зв’язку навчання, науки та виробництва) [8];

2) активна підтримка Болонського процесу, метою якого є об'єднання ЄПВО i європейського наукового простору - основ суспільства знань - через підвищення якості системи вищої освіти, сприяння мобільності студентів, викладачів та керівників освіти, забезпечення навчання протягом всього життя [37];

3) обмін досвідом модернізації вищої освіти у різних країнах;

4) підтримка програми сприяння студентській мобільності Erasmus;

5) співробітництво з міжнародними програмами модернізації вищої освіти, зокрема Erasmus Mundus - підвищення якості вищої освіти через світову академічну мобільність і співпрацю;

6) європейські студії з перспективних напрямів розвитку освіти.

Огляд напрямів підтримки вищої освіти й останніх звітів Європейської Комісії [36] показує, що ключем до побудови європейського освітньо-наукового простору є мобільність, адже головним проявом спрямованості системи освіти на особистість $є$ створення для будь-якого члена суспільства можливості отримання освіти будь-якого характеру і рівня в будь-який період його життя і в будь-якому місці [30]. Розвиток інформаційно-комунікаційних технологій (IКТ) створив умови для виникнення i розвитку інноваційних технологій дистанційного, електронного, комбінованого та мобільного навчання. Остання технологія уособлює ключові характеристики розвитку ЄПВО: мобільність усіх суб'єктів навчання, неперервність освіти, навчання протягом усього життя, особистісна орієнтація навчання, дослідницький підхід у навчанні, інноваційність, соціально-конструктивістський підхід до організації навчання та ін.

Досвід реформування європейської системи вищої освіти показує, що розв'язання проблеми підвищення якості освіти вимагає комплексного використання інноваційних технологій і засобів навчання. Упровадження мобільного навчання в систему вищої освіти України має неоціненне значення для пї модернізації й інтеграції у ЄПВО, оскільки наша держава географічно й історично європейська, у політичній, економічній, соціальній i духовній сферах зорієнтована на загальноєвропейські цінності й освітні стандарти. Зважаючи на те, що станом на 2015 рік Україна не є членом Свропейського Союзу, вона тісно співпрацює з його керівними органами в усіх галузях, і найдовше - у галузі науки й освіти.

Аналіз останніх досліджень і публікацій. Як зазначає О. І. Локшина, в умовах посилення прогностичної функції порівняльної педагогіки провідним напрямом досліджень є виявлення тенденцій [77, с. 5]. Історико-педагогічні, філософські та соціально-економічні тенденції розвитку вищої освіти у країнах Європейського Союзу досліджували М. Г. Балихін [49], В. Г. Грачова [53], Н. М. Дем'яненко [56], Т. М. Десятов [57], С. Г. Заскалєта [60], В. І. Іванова [61], Т. С. Кашлачова [63], А. Г. Кирда [64], Т. М. Козак [65], К. В. Корсак [68], П. В. Кряжев [69], М. М. Кудря [72], Н. М. Лавриченко [75], Л. О. Лазарєва [76], О. В. Маклакова [80], О. В. Мартинова [81], Г. О. Мошляк [84], Н. В. Негребецька [85], Л. В. Онищенко [87], Г. Г. Поберезська [89], О. В. Поживілова [90], Л. М. Полуніна [91], Л. С. Постова [92], Н. А. Рижова [95], А. А. Сбруєва [96], О. В. Тряпіцин [104], Н. С. Філатова [106], В. М. Чистохвалов [108], Б. І. Шуневич [109]. Дослідники визначають концепцію мобільності (навчальної, академічної, географічної, професійної тощо) як системотвірну для ЄПВО. Застосування концепції мобільності до процесу навчання викликало до життя поняття мобільного навчання (mobile learning).

Дидактичні аспекти мобільного навчання досліджували Я. Бартелсен (Jan Bartelsen) [5], Б. Бахмайр (Ben Bachmair) [13], Т. О. Калуга [62], В. О. Куклєв [73], С. В. Кувшинов [70], А. Кукульска-Хьюм (Agnes Kukulska-Hulme) [38], С. Лубіна (Eva 
Lubina) [78], К. Майєр (Katja Mayer) [13], М. Ріш (Maren Risch) [13], С. О. Семеріков [97], I. О. Теплицький [97], Дж. Тракслер (John Traxler) [40; 41], К. Фрідріх (Katja Friedrich) [13], М. Шарплз (Mike Sharples) [38], С. В. Шокалюк [97]. Технологічні аспекти мобільного навчання висвітлювались у роботах Д. Кігана (Desmond Keegan) [23], М. М. Козяра [66], А. Д. Кузика [66], М. Кужби (Масіеј Kuszpa) [28], В. О. Куклєва [73], М. Кьолера (Michael Köhler) [27], М. М. Мотіна [83], В. В. Осадчого [88], Н. В. Рашевської [94], С. О. Семерікова [97], І. О. Теплицького [97], В. Д. Ціделка [74], Е. Шерма (Ewald Scherm) [28], С. В. Шокалюк [97]. Моделі мобільного навчання були предметом розгляду 3. В. Дудар [58], В. О. Куклєва [73], В.В.Любченка [79], O. П. Поліщука [102], I.О. Теплицького [102], О.С.Шинкарюка [79]. Методика використання засобів мобільного навчання розроблялась В. А. Гаманюк [52],

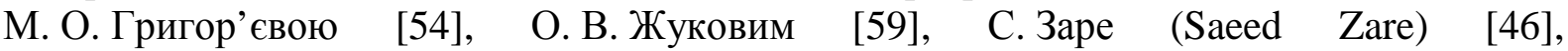
Є. Г. Михалкіною [82], С. О. Семеріковим [97], К. І. Словак [99], І. О. Теплицьким [97], Ю. В. Триусом [103], С. В. Шокалюк [97].

Зважаючи на комплексні дослідження поточного стану і перспектив розвитку мобільного навчання у країнах Свропейського Союзу [39] і світу [2], виконані в рамках освітньої і культурної програми Socrates, систематичного дослідження вимагають питання:

- форм організації, методів та засобів мобільного навчання студентів у системах вищої освіти країн Європейського Союзу;

- спільного й особливого в реалізації мобільного навчання студентів у системах вищої освіти країн Свропейського Союзу;

- перспектив розвитку мобільного навчання студентів у системах вищої освіти країн Європейського Союзу;

- використання європейського досвіду мобільного навчання студентів у системі вищої освіти України.

Компаративний аналіз тенденцій розвитку систем вищої освіти країн Європейського Союзу й України виявив такі суперечності:

- між необхідністю забезпечення всеохоплюючої мобільності навчання студентів у системі вищої освіти і реалізацією лише окремих ії складових;

- між потенціалом мобільного навчання студентів у системі вищої освіти i недостатнім його психолого-педагогічним супроводом;

- між станом наукових компаративістських досліджень досвіду мобільного навчання студентів, накопиченого за кордоном у цілому і в країнах Європейського Союзу зокрема, і потребами його наукового осмислення й ефективного використання в Україні.

Відкритим залишається питання співвідношення видів мобільності у соціальнопедагогічних і технічних системах (реальної, віртуальної, географічної, соціальної, професійної, академічної, навчальної, програмної, апаратної, технологічної), мобільних комунікацій та інформаційного суспільства, що зумовило визначення мети статті: теоретичне обгрунтування 1) співвідношення видів мобільності у соціальнопедагогічних i технічних системах; 2) інтегративної моделі мобільності в інформаційному суспільстві.

\section{2. РЕЗУЛЬТАТИ ДОСЛІДЖЕННЯ}

У найширшому сенсі поняття мобільності можна визначити як здатність (готовність) до руху, змін. Саме слово «мобільність» походить від латинського «mobilitas» [1, с. 238-239] й увійшло до основних європейських мов не пізніше кінця XV ст. 
«Великий тлумачний словник сучасної української мови» визначає «мобільність» як іменник до «мобільний», а останній, у свою чергу, як «1. Здатний до швидкого пересування; рухливий. 2. Здатний швидко орієнтуватися в ситуації, знаходити потрібні форми діяльності» [51, с. 682]. «Рухливий» потрактовано як «1. Який перебуває у русі. // Здатний до руху. // Який рухається завдяки своїй будові (про пристрій, механізм тощо). 2. Повний життєвої сили, енергії, зі швидкими, легкими рухами; жвавий. // Який легко переходить у рух (про частини тіла). // Який часто змінює свій вираз (про обличчя). // Діяльнісний, енергійний (про характер, склад розуму). 3. Який розвивається, змінюється» [51, с. 1280].

Спорідненість «мобільності» і «рухливості» відображається й у генезисі латинського «mobilitas»: староанглійське «mobyll» й англо-французьке «moble» еволюціонувало також й у «movēre» (сучасною англійською «to move» - «рухатися»). Мовами країн Європейського Союзу «мобільний» перекладається як «mobile» (англійська, італійська, словенська, фінська, французька), «mobil» (данська, німецька, румунська), «mobilní» (чеська, шведська), «mobilný» (словацька), «mobiilne» (естонська), «mobilan» (хорватська), «mobiel» (нідерландська), «mobbli» (мальтійська), «mobils» (латиська), «mobilus» (литовська), «móvel» (португальська), «móvil» (іспанська), «mozgó» (угорська), «hareketli» (турецька), «soghluaiste» (ірландська),

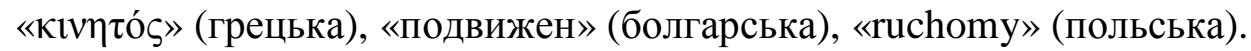

Мобільність $є$ сучасною міждисциплінарною парадигмою в соціальних $\mathrm{i}$ гуманітарних науках, яка досліджує переміщення людей, ідей і речей, а також наслідки цих рухів. Як зазначає М. Шеллер (Mimi Sheller) [34], у соціально-гуманітарних науках за останні десять років сформувався новий підхід до вивчення мобільності: комплексне дослідження спільного руху людей, об'єктів та інформації. У межах цього підходу досліджуються співвідношення мобільності і сталості, умови «завершення руху» (переходу до сталого стану) у вимірі «соціум - простір», зв'язок мікровпливів і макроструктурних перетворень у соціальних і технічних системах.

Хоча історично поняття мобільності є достатньо давнім, а основний зміст його усталеним, зміни у світі на початку XXI століття стають все швидшими, а сам світ змінюється більше, динамічніше та більш складними шляхами, ніж раніше, у той же час стикаючись 3 новими проблемами примусової мобільності і нерівномірної мобільності, екологічними обмеженнями i змінами клімату, що ведуть до непередбачуваних ризиків. Намагання їх зменшити привели до появи загальної концепції стосовно необхідності встановлення балансу між задоволенням сучасних потреб людства і захистом інтересів майбутніх поколінь, включаючи їхню потребу в безпечному і здоровому довкіллі - сталого розвитку [86]. Її упровадження веде до зменшення небажаної мобільності (наприклад, руху сміття [105, с. 201]).

Засновник мобільної соціології Дж. Урpi (John Urry) ставить перед нею завдання аналізу реальної і віртуальної мобільності людей, спрямованої на задоволення їхніх потреб і зменшення ризиків. Мобільна соціологія аналізує, як глобальні мережі й потоки змінюють соціальні структури [105, с. 201]. М. Шеллер наголошує, що багато частин світу стоїть на порозі великих перетворень в існуючих соціально-технічних системах завдяки мобільності і комунікації [34]. В інформаційному суспільстві комп'ютерні мережі та інші засоби інформаційно-комунікаційних технологій сприяють глобалізації, розвитку міжнародного ринку праці, зростанню різних видів індивідуальної мобільності особистості.

Дж. Уррі визначає п’ять основних напрямів реалізації мобільності («русел», або «каналів» у авторській термінології): перший - транспорт як забезпечення мобільності людей, другий - поштова система іа вантажоперевезення як засіб забезпечення мобільності речей, третій - кабельні системи (телефонні, телевізійні та комп'ютерні), 
четвертий - наземні безпровідні системи передавання звуку, зображення та інформації, і п'ятий - супутникові і позаземні системи. Сама концепція «каналу» вперше з'явилась у роботі Дж. Д'юї (John Dewey) «Демократія і освіта» (1916р.): «Ми побачимо мобільне суспільство, насичене каналами поширення змін, що відбуваються будь-де, лише тоді, коли його члени будуть освічені, ініціативні та адаптивні» [55, с. 88] - саме у цьому Дж. Д’юї вбачав демократичний ідеал. За часів Дж. Д'юї такими каналами комунікації були міграційні потоки (перший канал Дж. Уррі), трансатлантичні пошта (другий канал), телеграфний (третій канал) і радіозв'язок (четвертий канал). «Не тільки соціальне життя ідентичне комунікації, але й усі комунікації (i, отже, усе справжнє соціальне життя) є освітніми. Для того щоб стати суб'єктом комунікації, необхідно розширити і змінити свій досвід» [55]. Під комунікацією Дж. Д'юї розумів не лише передавання та отримання повідомлень (інформаційний аспект), а й обмін досвідом (освітній аспект). Згідно з Дж. Д’юї, комунікація є головним освітнім процесом. Концепція освіти як ліберального обміну досвідом породила філософські i методологічні питання, які набувають нового наповнення в епоху мобільності [98, с. 98-99]: мобільна зв'язність у суспільстві і просторі посилюється із застосуванням мобільних пристроїв і «розумних» навчальних середовищ.

Мобільність людини може залежати від моторних навичок, спеціальних інструментів, транспортних засобів, доступності роботи та інших факторів. Так, у мобільних технологіях мобільність стосується характеристик пристрою для доступу до інформації, комунікації тощо у процесі переміщення людини.

Мобільна соціологія перекривається 3 деякими аспектами глобалізаційних досліджень, досліджень у галузі зв’язку і туризму, демографії та антропології, міграційних і прикордонних досліджень, культурної і транспортної географії.

У демографії і антропології мобільність населення вимірюється його міграцією всередині певної популяції. Географічна мобільність,, на відміну від демографічної, не $\epsilon$ обмеженою певною територією. Поняття географічної мобільності (рис. 1) виникає на початку XX століття: цікаво, що перша згадка про неї у звіті бюро працевлаштування Нью-Йорка 1909 року [11, с. 49] наводиться у контексті географічної мобільності праці.

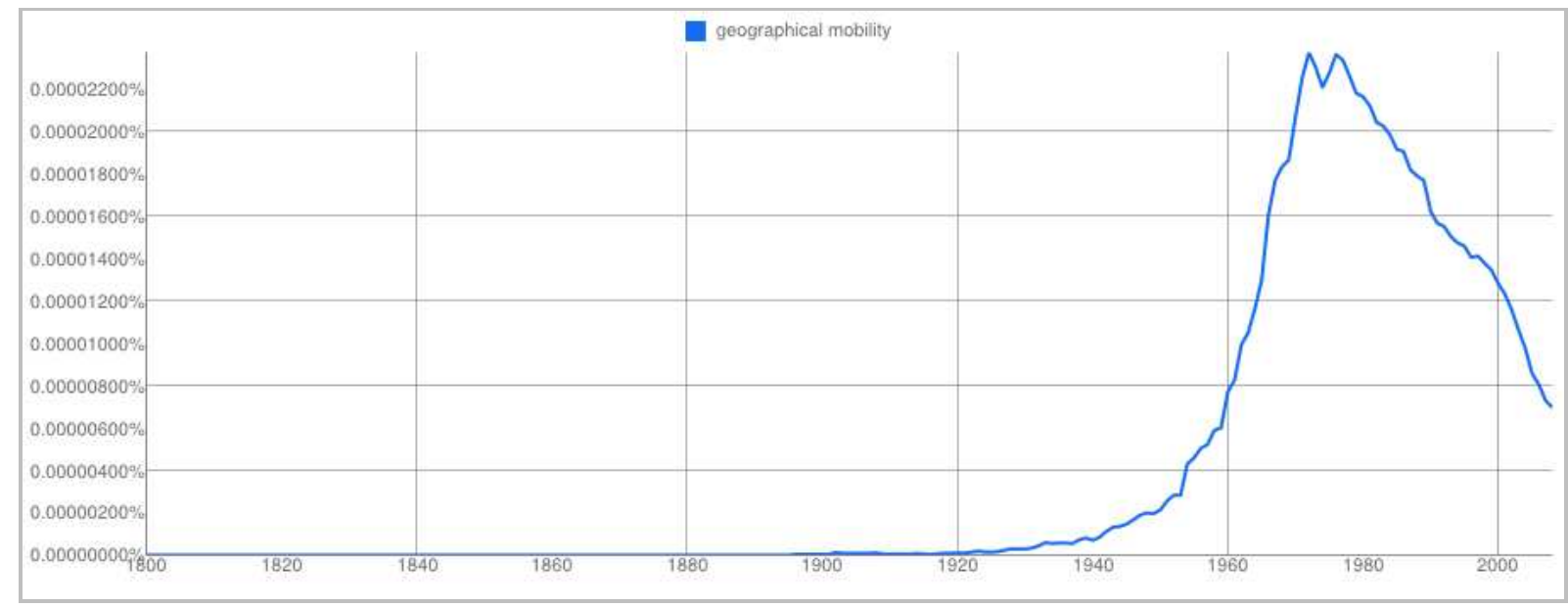

Рис. 1. Географічна мобільність у англомовних джерелах [16]

У соціологічній літературі мобільність, зазвичай, ототожнюється 3 ідеєю соціальної мобільності, що стосується здатності людей у суспільстві переміщатися між різними соціальними рівнями й економічними групами (економічна мобільність) [48]. Соціальна мобільність може бути пов' язана також із просторовим рухом (географічною 
мобільністю), культурним обміном (антропологічний аспект мобільності ідей) та інформаційним посередництвом (медіацією). Останні дві складові $\epsilon$ основою мережного підходу до навчання.

Уперше поняття соціальної мобільності (рис. 2) вводиться у II томі роботи Олександра фон Гумбольдта (Friedrich Wilhelm Heinrich Alexander von Humboldt) «Космос» $(1847$ р.) як одна 3 трьох характеристик «римського національного духу»: «соціальна мобільність, публічність та підтримка індивідуальності - головні опори вільних інститутів, що сприяють інтелектуальному розвитку» [22, с. 16]. М. Шеллер [34] услід за П. Ванніні (Phillip Vannini) стверджує, що соціальна, технологічна та інформаційна мобільність були найважливішими умовами існування давніх містдержав, морських імперій нового часу й індустріальних міст XIX століття так само, як і сучасних мегаполісів.

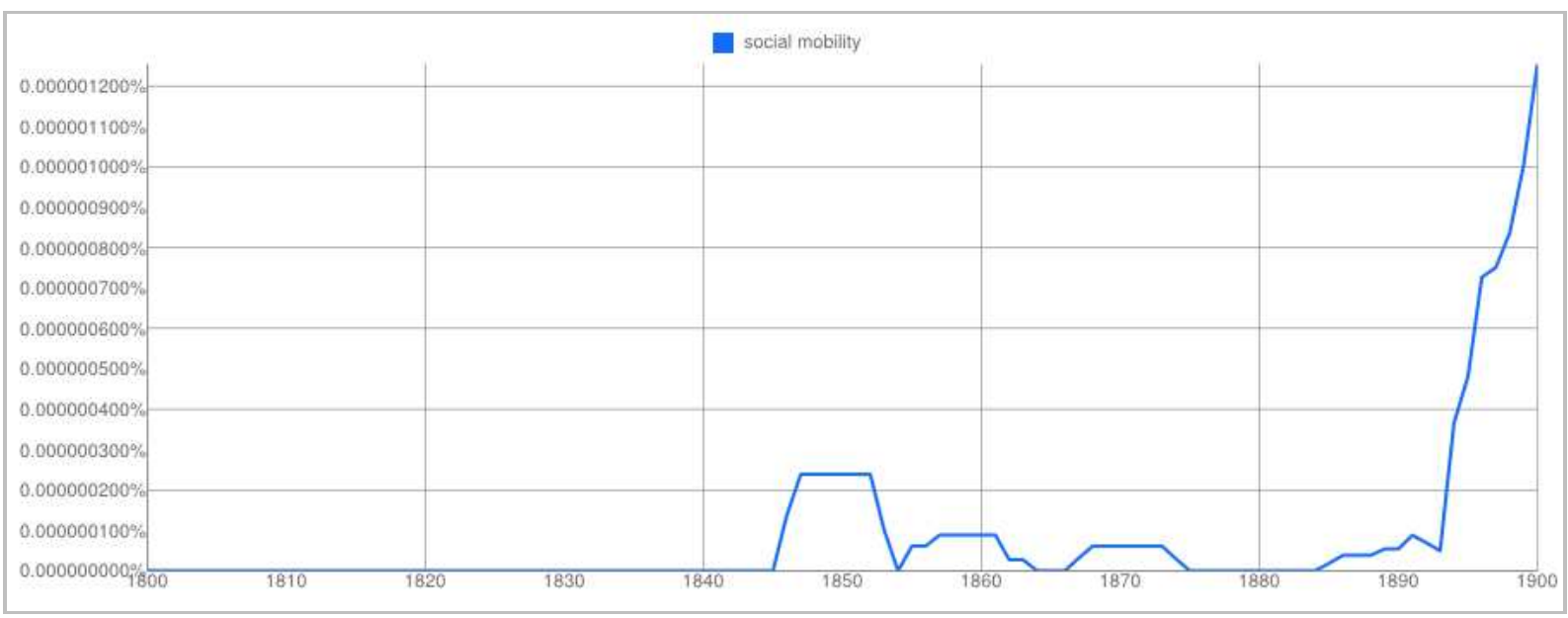

a)

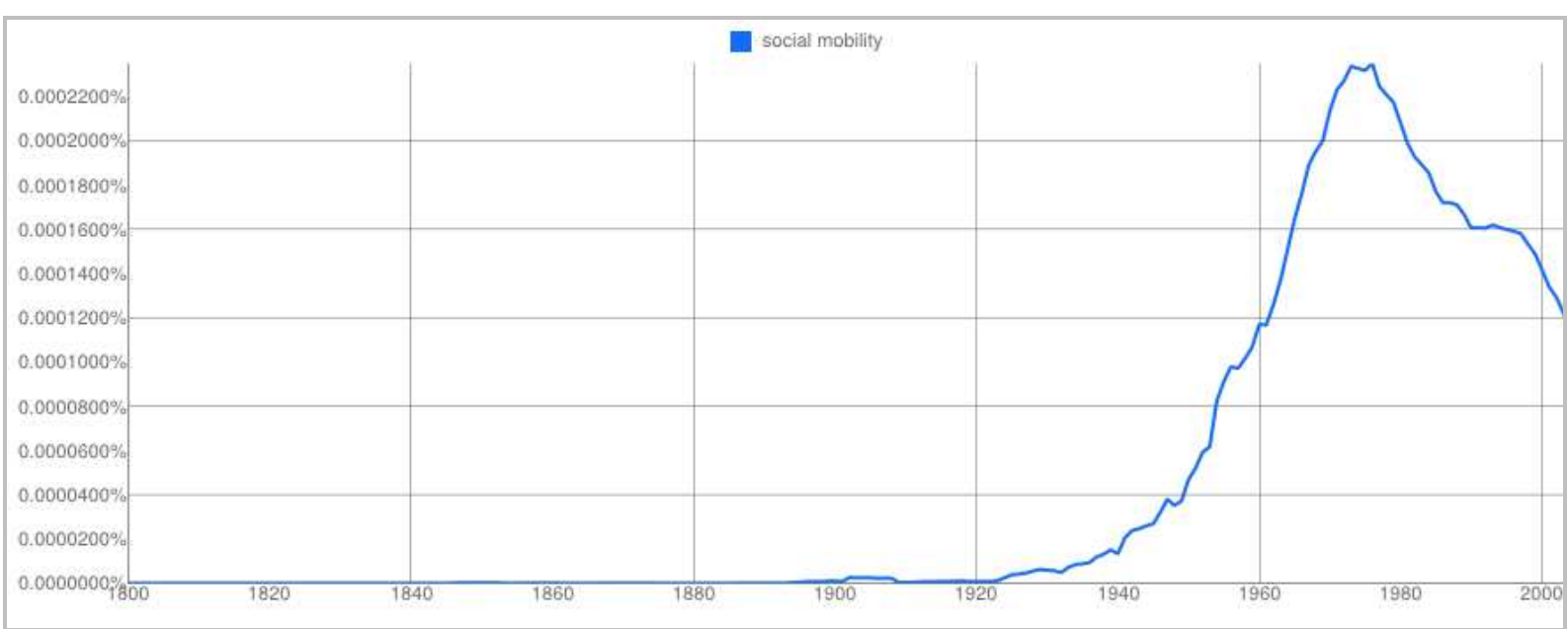

б)

Рис. 2. Сочіальна мобільність в англомовних джерелах XIX (а) i XX cm. (б) [16]

На відміну від традицій соціологічного дослідження соціальної мобільності, мобільність як новий трансдисциплінарний напрям досліджень охоплює питання просторової мобільності людей і речей, циркуляцію повідомлень, зображень, капіталу тощо, а також вивчає фізичні засоби для руху, такі як інфраструктура, транспортні 
засоби та програмне забезпечення, використання яких надає можливість переміщуватися і здійснювати комунікацію, об’єднуючи чисто «соціальні» проблеми соціології (нерівність, влада, ієрархія) 3 «просторовими» проблемами географії (територія, кордони, масштаб) i «культурними» проблемами антропології і медіастудій (дискурси, уявлення, схеми). Утім, сам рух може бути не тільки реальним (географічна мобільність чи фізичне переміщення об'єктів), а й уявним (уявлювані подорожі, віртуальні екскурсії тощо), надаючи можливість людям жити більш «мобільним життям» навіть за фізичних (матеріальних, соціальних та ін.) обмежень. Ураховуючи провідну роль комунікації у навчанні, така мобільність стає основою для організації віртуального (електронного) навчання: так, система віртуальної реальності Second Life успішно застосовується для навчання студентів [21].

Людина може мати високий ступінь віртуальної мобільності засобами мобільних комунікацій без необхідності фізичного переміщення (віддалена робота з високим рівнем професійної, соціальної та економічної мобільності), проте може й мати високий ступінь географічної мобільності без можливості зміни особистого вибору i компетентності (роз'їзна робота 3 низьким рівнем професійної, соціальної та економічної мобільності).

В. М. Аніщенко визначає професійну мобільність як одну з форм соціальної мобільності, що є процесом зміни робітниками місця праці [47]. У 1913 році у звіті бюро освіти США вводиться поняття професійної мобільності (рис. 3) учителів шкіл: «у професії [учителя] дуже бажана як розумна мобільність, так й розумна стабільність» [35]. С. А. Кугель, характеризуючи професійну мобільність науковців, виокремлює три основні iї фактори: внутрішньонауковий (логіка наукового дослідження), психологічний (зміна наукових інтересів), праксіологічний (практична корисність дослідження) [71, с. 96]. Утім, найменш ефективною $є$ мобільність, пов'язана 3 докорінною зміною сфери діяльності (перехід з науки до бізнесу тощо). Професійну мобільність кваліфікованого робітника Л. Л. Сушенцева трактує як необхідну для успішної життєдіяльності в сучасному суспільстві якість особистості, що виявляється у праці і забезпечує самовизначення, самореалізацію в житті і професії через сформованість ключових компетенцій і ключових кваліфікацій і прагненні особистості змінити не тільки себе, а й професійне поле і життєве середовище [101, с. 158].

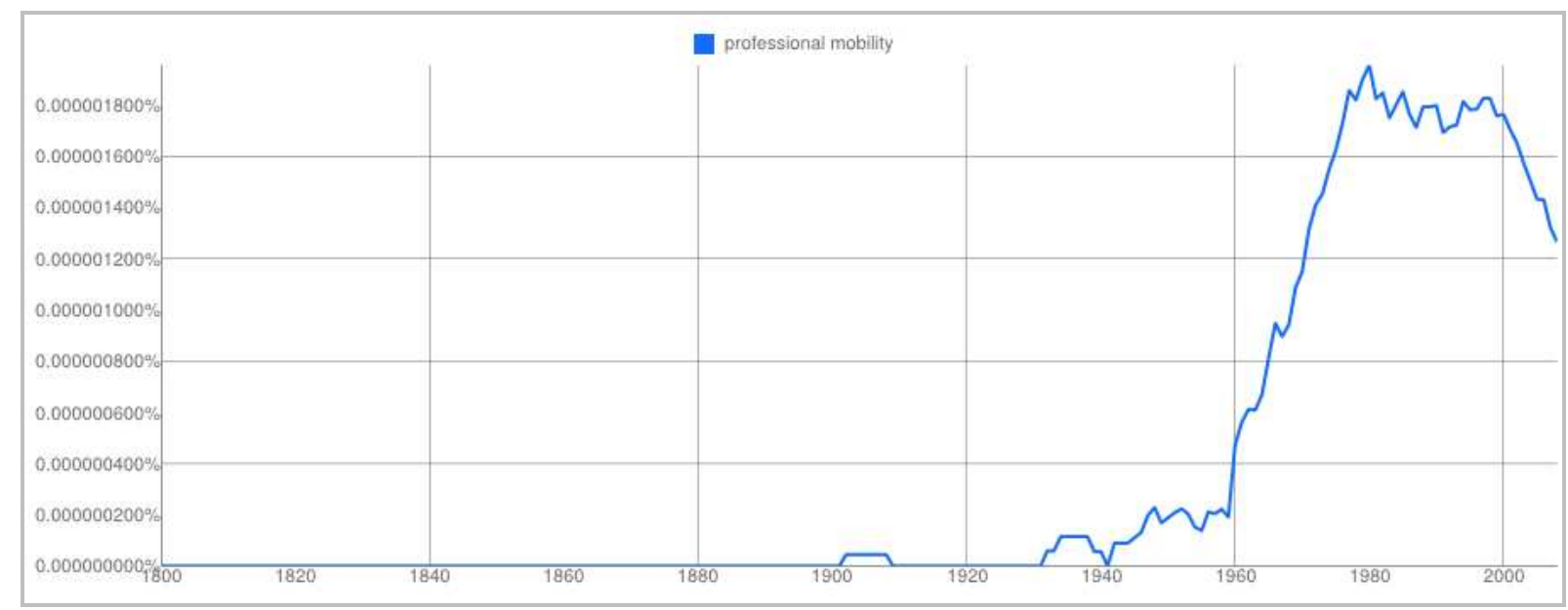

Рис. 3. Професійна мобільність в англомовних джерелах [16]

Ч. Шах (Chandra Shah) та Дж. Берк (Gerald Burke), розглядаючи заохочення мобільності кваліфікованих робітників, стверджують, що для того, щоб за їі допомогою розв'язати проблему дисбалансу розподілу кваліфікованих робітників усередині країни, 
необхідним є уніфікація визнання їх кваліфікації в усіх регіонах. Внутрішня міграція має більше шансів на успіх, якщо вона підкріплена комплексним інформуванням не лише про ринок праці, а й про інші послуги, такі як освіта, охорона здоров'я і житло. Великі відмінності у вартості житла в різних регіонах можуть зменшувати мобільність робочої сили [33, с. 326].

Як зауважує Ш. А. Лахмен (Shane A. Lachtman), «освіта є ключем для соціальної мобільності та показником ступеня меритократичності суспільства» [29, с. 542]. Мобільність освіти $є$ принциповою характеристикою єдиного освітнього простору, на формування якого спрямований, зокрема, й Болонський процес: достатньо згадати принципи Великої хартії університетів [50], у тому числі четвертий принцип - принцип мобільності, що розуміється в найширшому сенсі - мобільність знання. Його реалізація в академічній мобільності (можливості для студентів і викладачів переміщатися між різними освітніми установами всередині і за межами своєї країни) із самого початку (рис. 4) була тісно пов'язана із соціальною і професійною мобільністю: так, Е. Девіс (Allison Davis) i Дж. Доллард (John Dollard) у 1940 р. розглядали iii у контексті особистісного розвитку негритянської молоді у містах американського півдня [10, c. 57].

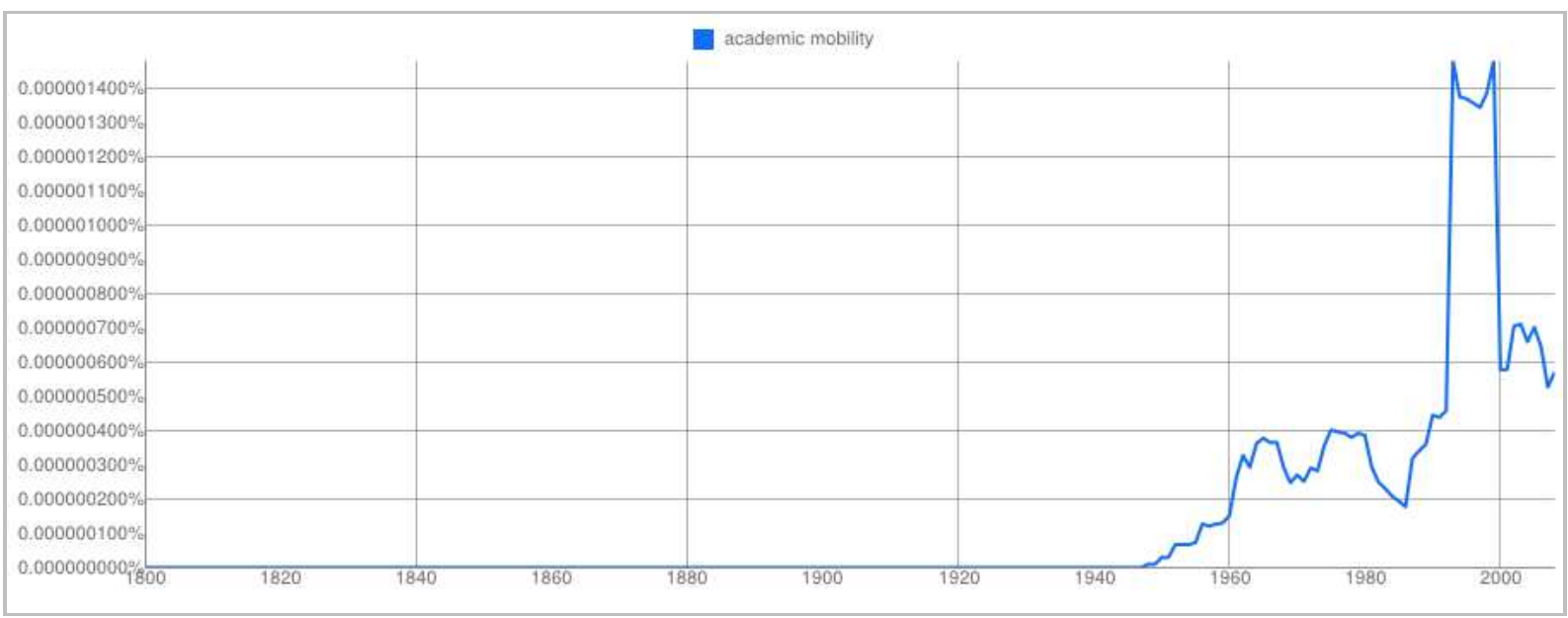

Рис. 4. Академічна мобільність в англомовних джерелах [16]

Е. Ко (Edmond Ко) уводить поняття студентської мобільності як здатності студентів навчатися або працювати після завершення навчання у ВНЗ, перетинаючи національні кордони [26, с. 209]. Дослідник підкреслює, що важливим наслідком глобалізації $\epsilon$ підвищення мобільності студентів, вступників та випускників університетів: особа, що має високий рівень мобільності, можете вчитися (бути академічно мобільною), працювати (бути географічно і професійно мобільною), співпрацювати й бути конкурентноздатною в будь-якій країні. Важливим наслідком цього $є$ зростання необхідності уведення міжнародних норм і стандартів, за допомогою яких академічні кваліфікації з різних країн можуть бути порівняні й визнані. Попри це, ураховуючи тенденцію до навчання протягом усього життя, необхідним $є$ також міжнародне унормування дистанційного навчання, підготовки, перепідготовки, підвищення кваліфікації тощо.

Сприятливим для академічної мобільності є створення і поширення філій вищих навчальних закладів за межами країни, що веде до мобільності постачальників освітніх послуг, освітніх проектів, навчальних програм і матеріалів тощо за допомогою таких нових форм, як комерційна концесія (франчайзинг), спільні ступені й партнерська співпраця (державна/приватна, некомерційна/комерційна, місцева/іноземна, 
установ/корпорацій). Нові типи партнерств формуються у відповідь на зростаючий попит на доступ до вищої освіти, а в багатьох випадках - здобуття іноземної академічної кваліфікації.

У розвитку академічної мобільності Дж. Найт (Jane Knight) виокремлює дві важливі тенденції. Перша тенденція - зміщення від мобільності студентів до програм і постачальників мобільності. Важливо відзначити, що кількість студентів, що прагнуть отримати освіту в зарубіжних країнах, як і раніше, зростає, але нині більше уваги приділяється доставлянню іноземних академічних курсів і програм студентам в їх рідній країні. Друга тенденція - зміщення орієнтації від співробітництва в цілях розвитку до конкурентоспроможної торгівлі [25, с. 510].

До нових програм мобільності Дж. Найт відносить [24, с. 383]:

- франчайзинг (franchise) - угода, за якою постачальник у країні-джерелі дозволяє постачальникові з іншої країни доставити в неї свій курс/програми/послуги;

- подвоєння (twinning) - тип транснаціональної освіти, у якому студент частину часу навчається в місцевому ВН3, а частину - у зарубіжних установах, пов'язаних із місцевим ВН3;

- подвійні/спільні ступені (double/joint degree) - тип освіти, за якого постачальники в різних країнах співпрацюють, дозволяючи студентам набирати кредити у кожного постачальника 3 метою отримання кваліфікації від кожного з них;

- поєднання (articulation) - тип освіти, що базується на домовленості між постачальниками, розташованими у різних країнах, що надають можливість студентам набрати кредити за узгодженими курсами/програмами, спільно пропонованими всіма постачальниками;

- нострифікація (validation) - домовленість між постачальниками у різних країнах, що дозволяють постачальнику у приймаючій країні присудити кваліфікацію постачальника у країні-джерелі;

- віртуальна/дистанційна (virtual/distance) - угода, за якою постачальники поставляють курси/програми для студентів у різних країнах у дистанційному й онлайнрежимі.

Постачальники мобільності можуть бути описані через фізичне або віртуальне переміщення навчального закладу (установи, організації, підприємства) через державні кордони 3 метою надання освітніх послуг студентам інших країн. На відміну від програм мобільності, постачальники мобільності не вимагають фізичного переміщення студентів. Кредити і кваліфікації присвоюються іноземним постачальником (іноземні, місцеві, власні) або афілійованим місцевим партнером. Основними видами постачальників мобільності є [24, с. 385]:

- філія - закордонний постачальник створює в іншій країні свою філію, надаючи студентам іншої країни свої курси і програми та присуджуючи власну кваліфікацію;

- автономна установа - іноземний постачальник (університет, компанія, або альянс/мережа) створює в іншій країні автономний ВНЗ, який не має батьківського у країні постачальника, що пропонує курси/програми і присуджує кваліфікацію;

- придбання/злиття - іноземний постачальник купує частину або $100 \%$ місцевого $\mathrm{BH} 3$;

- навчальний центр/навчальний сайт - іноземний постачальник організує навчальний центр у іншій країні (що співпрацює 3 місцевими постачальниками або $є$ незалежним від них) для підтримки студентів з опанування їх курсів/програм;

- аффіліація/мережі - різні види державних і приватних, традиційних і нових, місцевих та іноземних постачальників, що співпрацюють у рамках інноваційних типів партнерств щодо створення мереж/установ із доставляння курсів і програм місцевим i зарубіжним студентам у традиційний або дистанційний спосіб; 
- віртуальний університет - постачальник, який надає освітні послуги студентам у різних країнах за допомогою дистанційної освіти 3 використанням переважно Інтернет-технологій, як правило, без підтримки очного навчання.

M. ван дер Венде (Marijk van der Wende) наголошує, що віртуальні програми мобільності й віртуальні університети нині $є$ основою віртуальної мобільності студентів, що базується на використанні нових ІКТ у вищій освіті, насамперед Інтернет і мобільних навчальних середовищ [45]. Електронне навчання (e-learning) сприяє глобальному доступу до вищої освіти, сприяючи педагогічним інноваціям і зниженню вартості навчання. Нині віртуальні університети і комбіноване навчання складають серйозну конкуренцію традиційним університетам й очному навчанню [100].

C. Авведуто (Sveva Avveduto) [4, с. 286], характеризуючи мобільність аспірантів та науковців, вказує, що мобільність висококваліфікованих фахівців може розглядатися 3 різних точок зору: як політичне питання витоку/притоку людських ресурсів («витік мізків»), як проблема справедливості розподілу людських ресурсів між регіонами, що знаходяться на різних рівнях розвитку, як проблема політики міграції та iн.

Людські ресурси є важливим елементом суспільно-економічного розвитку, і всі інвестиції в їх освіту і доцільне використання вважаються необхідними для загального благополуччя суспільства й економіки.

У цьому контексті інтернаціоналізація освіти і науки є основними компонентами, що сприяють розвитку «найкращої робочої сили»- робочої сили, що займається дослідженнями у галузі науки і технологій, що складається насамперед 3 аспірантів і науковців, для яких мобільність $є$ ефективним засобом поширення і взаємопроникнення знань і технологій.

Межа між мобільністю і міграцією для висококваліфікованих фахівців часто стає менш очевидною. С. Авведуто вважає, що у глобалізованому суспільстві недоречно ототожнювати мобільність аспірантів і учених 3 їх прагненням вирватися 3 країни походження: швидше за все слід розуміти їі як вільне пересування людей та ідей, а не як «перетікання» інтелекту.

Необхідність конкурувати, співпрацювати і працювати 3 іншими вченими $\epsilon$ органічною властивістю науково-дослідної діяльності. Четвертим принципом Великої Хартії Університетів [50], підписанням якої у 1988 р. розпочався Болонський процес, $\epsilon$ наступний: «Університет $є$ хоронителем традицій європейського гуманізму. У здійсненні свого покликання він постійно прагне до досягнення універсального знання, перетинає географічні і політичні кордони і затверджує нагальну потребу взаємного пізнання і взаємодії різних культур». Для досягнення цієї цілі вимагаються ефективні засоби, що відповідають теперішнім умовам: «Університети, особливо європейські, розглядають взаємний обмін інформацією і документацією, а також збільшення кількості спільних проектів для розвитку освіти, як основний елемент постійного прогресу знань. Тому, як і в ранні періоди своєї історії, вони стимулюють мобільність викладачів і студентів, а також розглядають загальну політику в питанні рівного статусу, звань, іспитів (без упередженого ставлення до національних дипломів) i присудження стипендій як необхідний інструмент для здійснення своєї місії».

Європейські університети відіграють вирішальну роль у просуванні академічної мобільності. Кожен університет має власні стратегії і програми вищої і післявузівської освіти, надаючи висококваліфікованим членам академічної спільноти різні види мобільності: від короткострокової відпустки до цілорічного тимчасового працевлаштування. Питання в тому, щоб визначити оптимальну частку мобільності в кар'єрі, у навчальному закладі або у країні. Якщо ця частка перевищена або не досягнула оптимальна ii величина, можуть виникнути проблеми. Надлишок 
мобільності може викликати менше проблем, ніж його відсутність.

За даними Ж.-К. Дюмона (Jean-Christophe Dumont) i Ж. Леметра (Georges Lemaître) [12, с. 13], найпривабливішими для іммігрантів 3 інших країн є Австрія, Франція, Німеччина, Іспанія, Чехія, Швеція, Великобританія, Бельгія, Греція, Португалія, Люксембург та Нідерланди. Найбільша кількість емігрантів виїжджає 3 Польщі, Ірландії, Фінляндії та Угорщини. У таких країнах, як Великобританія, Німеччина та Франція, спостерігається значна еміграція на тлі ще більшої імміграції, що свідчить про надвисоку мобільність фахівців з вищою освітою.

Зазвичай, немає стандартного інструменту, який може допомогти у визначенні обсягу оптимального рівня мобільності. Утім, аналіз позитивних і негативних наслідків мобільності може допомогти у виборі правильного балансу. На індивідуальному, інституційному або національному рівні переваги наявності мобільної висококваліфікованої робочої сили і співробітництва, вивчення і досвід роботи в іншому середовищі із зарубіжними партнерами, досить очевидні i позитивні можливості цього досвіду говорять самі за себе. Ризики пов'язані в основному 3 відсутністю можливості повною мірою розвивати позитивні сторони цього досвіду або зміни характеру мобільності - від тимчасового досвіду до постійного стану мобільності.

Проведене у 2003 році опитування науковців країн Свропейського Союзу [4, c. 290] показало, що найбільшими факторами мобільності виступають кар'єрне зростання (88\% опитаних), репутація роботодавця (74\%), доступ до передових технологій (73\%), фінансування науково-дослідних і дослідно-конструкторських робіт (70\%), професійна мережа (68\%), можливості трудової/підприємницької діяльності (56\%), зарплата (54\%), пригоди (49\%), освіта (46\%).

Мобільність учених і аспірантів як явище сягає своїми коренями середніх віків. Найперші ознаки мобільності в середньовіччі можна знайти в університетських студентів, відомі як clerici vagantes (мандрівні студенти, колишні студенти та навіть професори), і вони користувалися можливостями для переміщення всередині і за межами країни, щоб відвідати кращі університети, кожен 3 яких мав свою спеціалізацію, де студентська еліта могла знайти кращі знання і кращих учителів: у Болонському університеті - першу юридичну школу середньовічної Свропи, у Паризькому університеті - факультети вільних мистецтв, канонічного права, медицини та теології. Багато чого, якщо не все, з тих пір змінилося, але суть мобільності полягає в переміщенні 3 метою знайти найкращі варіанти праці і навчання, познайомитися 3 новими способами мислення, зіставити 3 іншими культурами й ідеями, а також зрозуміти, що відбувається за межами власного інтелектуального середовища.

У Новий час мобільність висококваліфікованих кадрів проявляється в різних формах і з різною інтенсивністю, починаючи із середини XIX століття і поширюється на початку XX століття, коли наука і наукова кар'єра набувають належного рівня. Зростає кількість елітних мігрантів, у тому числі фахівців і вчених, які залишили свої країни для того, щоб почати новий бізнес або вести культурну і наукову діяльність, важливу для низки країн i сфер промисловості - у фірмах, науково-дослідних лабораторіях і університетах. Міграція зростала під впливом багатьох чинників, у тому числі до і під час Другої світової війни через політичні або расові переслідування. За таких умов, наприклад, багато вчених змушені були мігрувати до США з Свропи. У цьому випадку доцільно використовувати термін «витік мізків», а не мобільність. Зауважимо, що й на теперішній час серед країн-членів Організації економічного співробітництва та розвитку (OECD) найбільш привабливими для учених є США i Канада.

Проведений OECD у червні 2013 р. аналіз чинників, що сприяють мобільності 
вчених і аспірантів (рис. 5), надав можливість визначити основні три чинники мобільності: академічні фактори (міграція - 43.9\%, повернення - 27.5\%), інші фактори, пов'язані з роботою і працевлаштуванням (міграція - 30.9\%, повернення $-23.6 \%$ ), та сімейні або особисті причини (міграція $-15 \%$, повернення - 20.6\%) [3, с. 40]. У країнах Європейського Союзу найбільший вплив академічних факторів на виїзд учених i аспірантів 3 Португалії (64.1\%), Іспанії $(54.1 \%)$ та Мальти $(46,6 \%)$, а найчастіше повертаються учені й аспіранти у Болгарію $(58,7 \%)$, Португалію $(39,1 \%)$ та Угорщину $(39,0 \%)$.

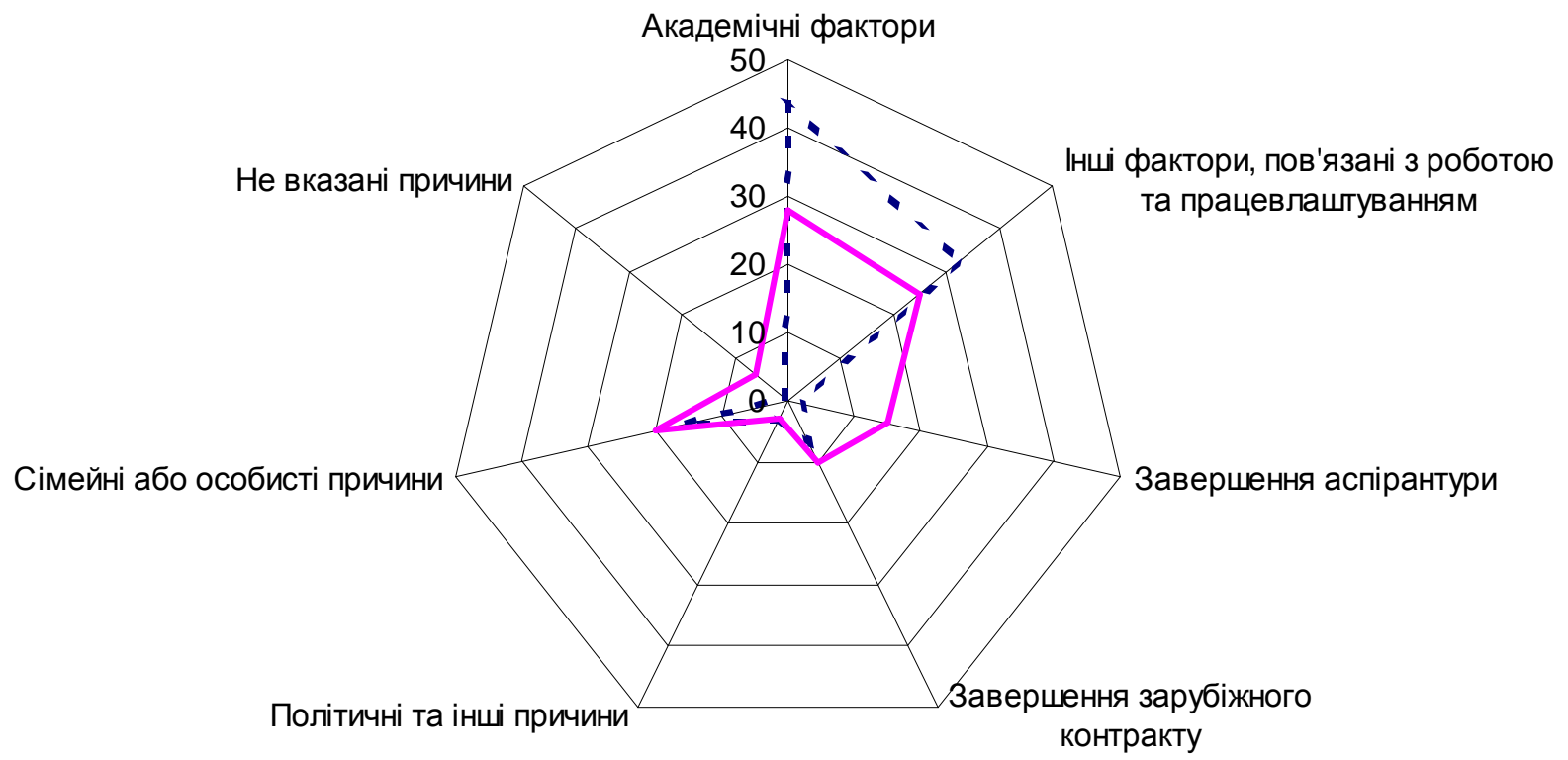

- - 'Виїзд — Повернення

Рис. 5. Чинники мігращиї аспірантів і науковців (за даними ОЕСD)

Отже, «витік мізків» можна охарактеризувати як перевищення виїзду над поверненням. У його сучасному розумінні термін «витік мізків» з'явився наприкінці 1950-х рр. і був використаний в офіційному документі Королівського товариства в 1963 р. для пояснення відтоку британських учених 3 країни [15]. Це поняття відноситься до надлишку маси талановитих людей, які змушені покинути свою країну, щоб знайти кращі умови наукової праці. Як зазначають Л. Opioль (Laudeline Auriol), M. Micy (Max Misu) i P. А. Фріман (Rebecca A. Freeman) [3, с. 29], рівень задоволеності зарплатою і пільгами у більшості країн є найнижчим. Середній рівень задоволеності стосується місця роботи, ступеня незалежності, інтелектуальної привабливості, рівня відповідальності, суспільної корисності та безпеки праці.

Мобільність аспірантів і вчених $\epsilon$, в основному, їх особистим вибором (можливість отримати досвід роботи за кордоном часто розглядається і сприймається як студентами, так і викладачами, як цінність сама собою), але може заохочуватися державними і міждержавними програмами й угодами, спрямованими на сприяння обміну дослідниками, адже у даний час підвищена мобільність вважається одним із показників здорової й інноваційної системи вищої освіти і науки. «Зелена книга» Єврокомісії «Європейський дослідницький простір» стверджує, що й уряди, й установи мають сприяти національній i міжнародній мобільності аспірантів і вчених як найважливішого елемента Свропейського дослідницького простору (ERA - European Research Area) - об’єднання наукового співтовариства, бізнесу та громадян, що має такі 
характеристики:

- адекватний потік компетентних дослідників з високим рівнем мобільності між установами, галузями науки і виробництва, країнами;

- дослідницька інфраструктура світового рівня, інтегрована, мережева та доступна для дослідницьких груп з різних країн Європи і світу, зокрема завдяки новому поколінню електронних комунікаційних інфраструктур;

- кращі науково-дослідні установи, що займаються ефективним державноприватним співробітництвом i партнерством, формуючи ядро дослідницьких й інноваційних «кластерів», включаючи «віртуальні дослідницькі спільноти», що, в основному, спеціалізується на міждисциплінарних дослідженнях і залучають критичну масу людських і фінансових ресурсів;

- ефективний обмін результатами досліджень, зокрема між дослідниками i промисловістю, а також із громадськістю в цілому;

- добре скоординовані дослідницькі програми і пріоритети, включаючи значний обсяг спільних програм 3 міждержавним фінансуванням на європейському рівні 3 урахуванням загальних пріоритетів;

- широка відкритість Європейського дослідницького простору світу з особливим акцентом на сусідні країни і спрямованість на розв'язанні глобальних проблем 3 партнерами в Свропі [19, с. 2-3].

Виконуючи програми досліджень, аспіранти можуть потребувати відвідування закордонних університетів і лабораторій для збору даних або виконання експериментів, не доступних у своїй країні. Але основні їхні досягнення пов'язані 3 особистим, культурним і науковим зростанням, яке вони можуть отримати під впливом різних наукових і навчальних середовищ.

Основним позитивним фактором мобільності учених є можливість знаходження у висококваліфікованому робочому оточенні, у якому вони отримують якісні результати, i вільний доступ до ресурсів і наукового обладнання. Негативними факторами мобільності, зазвичай, $\epsilon$ перешкоди, пов'язані з бюрократичними перепонами i труднощами в отриманні дозволу на роботу і візи на перебування. У зв'язку з цим у рамках ЄС були розроблені спеціальні норми для того, щоб полегшити в’їзд іноземних дослідників, які хочуть проводити наукові дослідження в рамках ЄС. Європейська комісія, наприклад, ввела Директиву 2005/71/ЕС від 12 жовтня 2005 року про особливу процедуру допуску громадян третіх країн 3 метою наукових досліджень [9] для регулювання процедури видачі спеціальних наукових віз.

Перепоною для мобільності аспірантів і молодих науковців $є$ насамперед загроза втратити можливості з працевлаштування у своїй країні або рідному місті: такі люди вважають за краще залишатись у рідному університеті, навіть якщо він знаходиться на більш низькому рівні й надає менші можливості для саморозвитку. Тим не менше, проблеми, пов'язані з «витоком мізків», усе ще не розв'язані: особливо це стосується країн, що розвиваються, у яких повернення талановитих дослідників у рідні країни після набуття досвіду мобільності дуже проблематичне. Повернення мобільного дослідника означає, що його рідна країна отримає нові знання i його досвід, управлінські навички тощо, врешті-решт стаючи більш конкурентоспроможною: дослідження М. Бейна (Michel Beine), Ф. Док’є (Fréderic Docquier) та Г. Рапопорт (Hillel Rapoport) показали, що подвоєння показника міграції висококваліфікованих фахівців приводить до 5\%-ого збільшення валових капіталовкладень на душу корінного населення [6].

Виникнення навчальної мобільності (рис. 6) було пов'язано з розвитком засобів i методів навчання осіб з особливими потребами [32, с. 186; 14]. Так, типовими послугами із забезпечення навчальної мобільності, що надаються студентам 3 
порушеннями зору, є досягнення систематичної орієнтації і безпечного пересування у середовищі ВНЗ, удома й у спільноті через використання інформації, отриманої за допомогою органів чуття (наприклад, звук, температура і вібрація) для встановлення, підтримки або відновлення орієнтації, і відповідних концепцій, методів та інструментів [31, с. 836]. Нині навчальна мобільність розглядається насамперед як короткотермінова академічна мобільність.

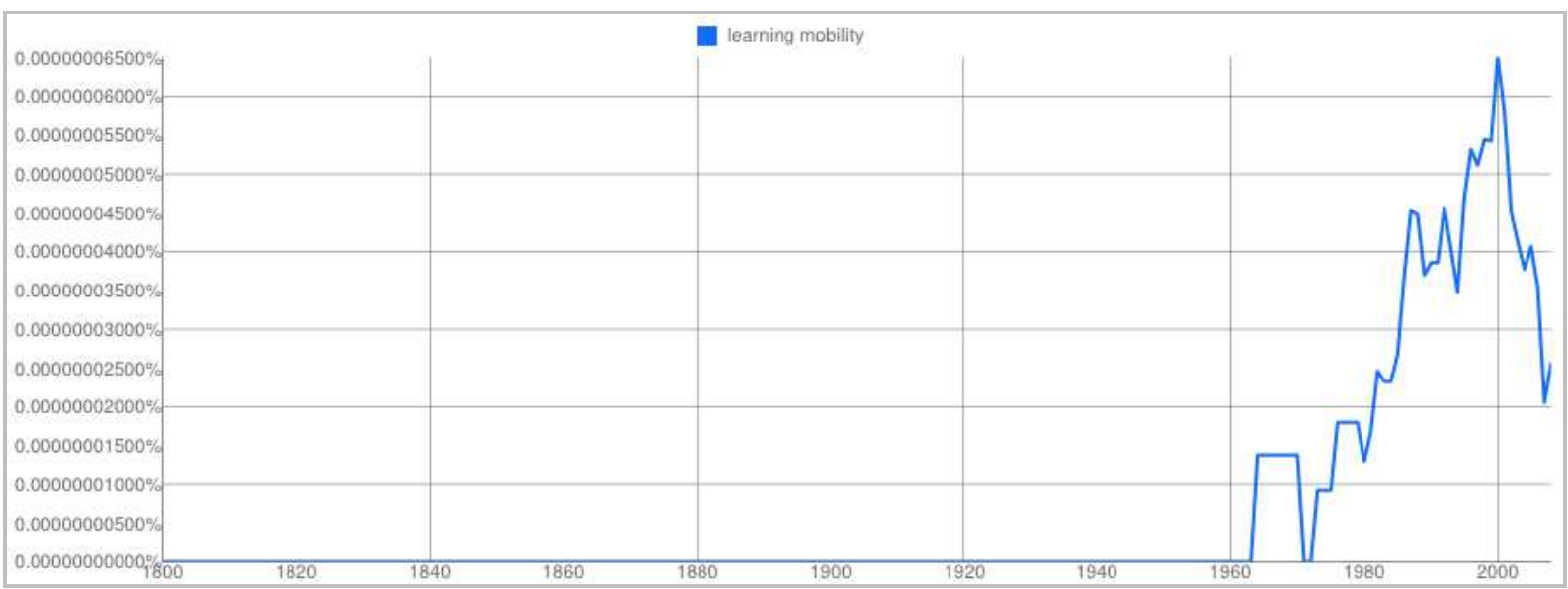

Рис. 6. Навчальна мобільність в англомовних джерелах [16]

Складність об'єктів і процесів, що досліджує мобільність, вимагає застосування системного підходу. Як стверджує Дж. Уррі, «усі потужні системи є динамічними, процесуальними ... і у сучасному світі $\epsilon$ одночасно економічними, фізичними, технологічними, політичними та соціальними» [43, с. 263] - адже «технології завжди вбудовуються в економічне, соціальне та політичне життя» [43, с. 264]. Зв'язки у таких системах посилюються за рахунок «програмної, кібернетичної архітектури та у цілому мережного характеру життя». Зважаючи на те, що теорія складності на перше місце ставить питання самоорганізації, синергіїв та саморозвитку систем, до сфери досліджень мобільності входять, у першу чергу, людинокеровані системи, у яких найбільший інтерес справляють види взаємодії людини з простором, з об'єктами і 3 іншими людьми, у тому числі за допомогою посередників (медіаторів) і гібридних спільнот. До таких систем відносяться й педагогічні системи, у яких мобільність може бути застосована для управління навчальною діяльністю.

Співвідношення основних видів мобільності (реальної і віртуальної) у соціальнопедагогічних системах подано на рис. 7. 


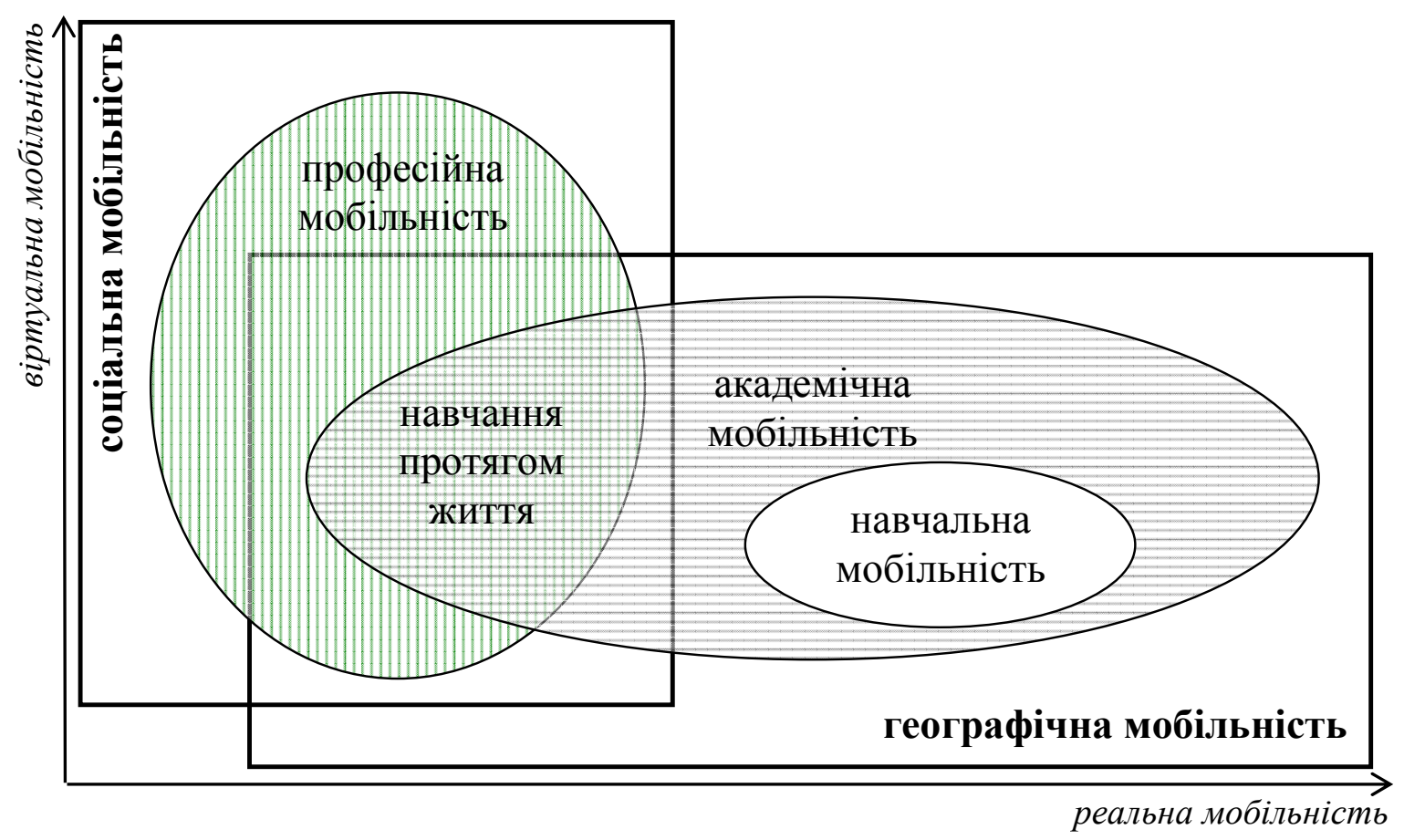

Рис. 7. Співвідночення видів мобільності у сочіально-педагогічних системах

Просторовий, матеріальний та часовий (швидкісний) виміри мобільності у системах мобільних комунікацій перетворюють сьогодення, породжуючи нові форми міського буття: «мережний урбанізм», «мережне місце», «мережна місцевість» [18]. Зв'язок немобільних і мобільних систем забезпечується через нерухомі платформи (передавачі, дороги, станції, супутникові антени, аеропорти, доки, заводи), що забезпечують географічну, трудову, економічну мобільність. Нові мобільні середовища перетворюють міський простір на технопростір і медіапростір, створюючи нові можливості для людей, для навігації у громадських місцях (доповнена реальність) і штучному середовищі (віртуальна реальність), породжуючи нові форми суспільної взаємодії у них (яскравим прикладом такого технологічного перетворення буття $\epsilon$ проект Google Glass - новий мобільний засіб доповненої реальності [17]). Серед нових напрямів досліджень проблеми мобільності М. Шеллер визначає, зокрема, такі: біфуркаційні процеси у складних системах, мобільні соціальні мережі, мобільні середовища, інформаційно-комунікаційні технології [34, с. 8].

Л. Г. Хоменко у 1998 р. вказував, що в останні десятиліття «центр уваги змістився ... на мобільність програмного продукту як міру уніфікації і подовження терміну його життя, можливість використання наступними поколіннями ЕОМ» [107, с. 395].

Мобільність програмного забезпечення В. О. Петрушин визначає як властивість, що полягає у можливості його перенесення з ЕОМ одного типу на ЕОМ іншого 3 низькими працевитратами $[67$, с. 328]. Цей вид мобільності $\epsilon$ важливим під час створення програмного забезпечення мобільного навчання. Під мобільністю пакета прикладних програм розуміють можливість перенесення його з одного операційного середовища в інше [98, с. 174]. Мобільність пакета прикладних програм $\epsilon$ «найважливішою властивістю пакетів прикладних програм ... [у комп’ютерній технології навчання], оскільки сприяє спрощенню їх тиражування, супроводу, а також полегшує навчання роботі з ними (не виникає необхідності повторного навчання у разі зміні технічної бази комп'ютерної технології навчання)» [67, с. 329].

Під програмною мобільністю (software portatibility) розумітимемо спільну для 
мобільності програмного забезпечення і мобільності пакета прикладних програм властивість, що передбачає можливість перенесення програм між різними операційними системами і між різними апаратними платформами.

3 рис. 8 можна побачити, що найбільшу уваги дослідників програмна мобільність привертала у 1985-1990 рр.: саме у цей час були закладені концептуальні основи сучасних мобільних операційних систем і засобів мобільних технологій.

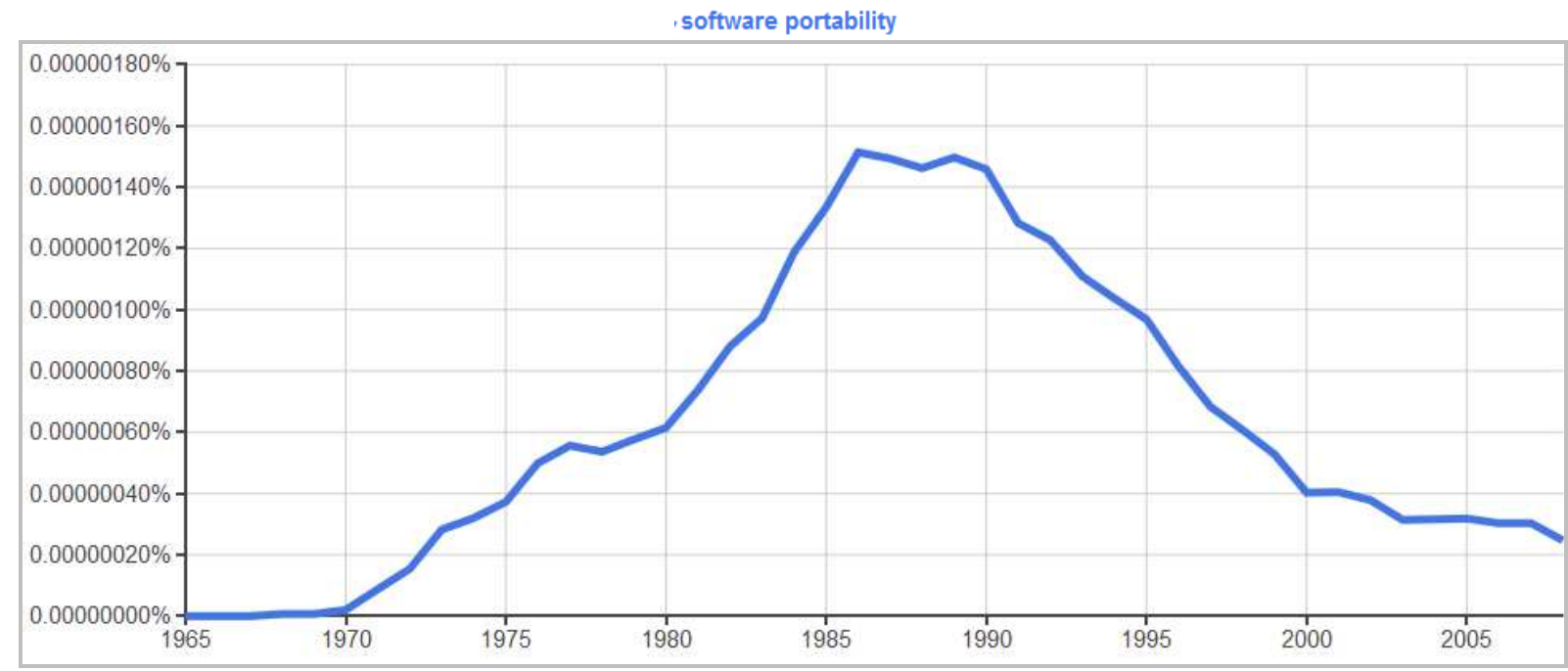

Рис. 8. Програмна мобільність в англомовних джерелах [16]

Перший систематичний виклад концепції програмної мобільності був здійснений У. С. Брауном (William Stanley Brown), який визначав ¥ї так: «Програму чи систему програмування називатимемо мобільною, якщо зусилля, необхідні для перенесення іiі у нове середовище суттєво менші за зусилля 3 iii перепрограмування у новому середовищі» [7, с. 80]. На думку У. С. Брауна, програмна мобільність необхідна також у випадках зміни типу комп'ютерної системи, щоб запобігти втраті програм, у створення і підтримку яких програмістами було вкладено багато зусиль. До засобів забезпечення програмної мобільності автор відносить, зокрема, мови високого рівня, у тому числі проблемоорієнтовані, поділяючи все програмне забезпечення на 4 класи за ступенем важкості перенесення: найлегше перенести невеликі процедури, важче - великі підсистеми, ще важче - компілятори, та найбільш важко - операційні системи.

Отже, найвищий рівень програмної мобільності досягається за використання однісї операційної системи на різних типах апаратних засобів (наприклад, Windows 10, що функціонує на спектрі пристроїв від телефону до персонального комп'ютера, або Android, що працює на різних апаратних мобільних платформах). Достатній рівень програмної мобільності досягається під час застосування мобільних трансляторів сучасним яскравим прикладом реалізації такої програмної мобільності $є$ віртуальні Java-машини.

Серед характеристик мобільності програмного забезпечення В. О. Петрушин визначає такі показники: 1) початкова вартість; 2) вартість перенесення; 3) обмеження перенесення; 4) неефективність [67, с. 328]. Кожен із показників є відсотковим вираженням відношення витрат на мобільне програмне забезпечення до витрат на традиційне програмне забезпечення.

Ці характеристики можна поширити й на інші види мобільності. Наприклад, для академічної мобільності:

1) показник початкової вартості включає витрати на забезпечення уніфікації 
шкали оцінювання і трансферу кредитів на основі ECTS, приведення навчальних планів і навчально-методичного забезпечення до вимог ECTS, створення Національної рамки кваліфікацій, інформаційну підтримку академічної мобільності тощо;

2) показник вартості перенесення включає витрати на забезпечення реалізації академічної мобільності у новостворених навчальних закладах або тих, що приєднались до нової програми мобільності;

3) показник обмеження перенесення визначається відсотком навчальних закладів (напрямів підготовки, складових освітніх систем тощо), для яких даний вид мобільності застосувати неможливо;

4) показник неефективності визначає усереднену неефективність реалізації мобільної системи порівняно із традиційною.

Під мобільністю апаратних засобів розумітимемо можливість їх руху у просторі за умови, що отримувані від такого руху переваги вище, ніж затрати на його забезпечення. За орієнтації на результат руху апаратний засіб вважатимемо мобільним, якщо одноразові витрати на його перенесення перекриваються перевагами його постійного використання у новому місці. Результатний підхід до визначення мобільності апаратних засобів $\epsilon$ відповідним географічній мобільності.

В орієнтації на процес руху апаратний засіб вважатимемо мобільним, якщо витрати на його рух перекриваються перевагами від його використання у процесі руху. Саме процесний підхід до визначення мобільності апаратних засобів нині є найбільш поширеним, тому доцільним є уведення характеристики апаратної мобільності як співвідношення часу використання пристрою у процесі руху до часу руху. Даний показник буде вищим для апаратного засобу, який легко переноситься (можна частіше використовувати під час руху, ніж між рухами), споживає мало енергії (можна довше використовувати під час руху) і є ергономічним (можна легше використовувати під час руху)

За процесного підходу мобільним комп'ютингом називатимемо людиномашинний інтерфейс, за якого очікується, що комп'ютер буде переноситися під час використання. Для забезпечення мобільного комп'ютингу необхідні мобільні комунікації, мобільні апаратні засоби (mobile hardware) та мобільне програмне забезпечення (mobile software).

3 рис. 9 видно, що інтерес до питання мобільності апаратних засобів, що виник наприкінці 1950-х рр., починаючи з 1980 р., постійно зростає.

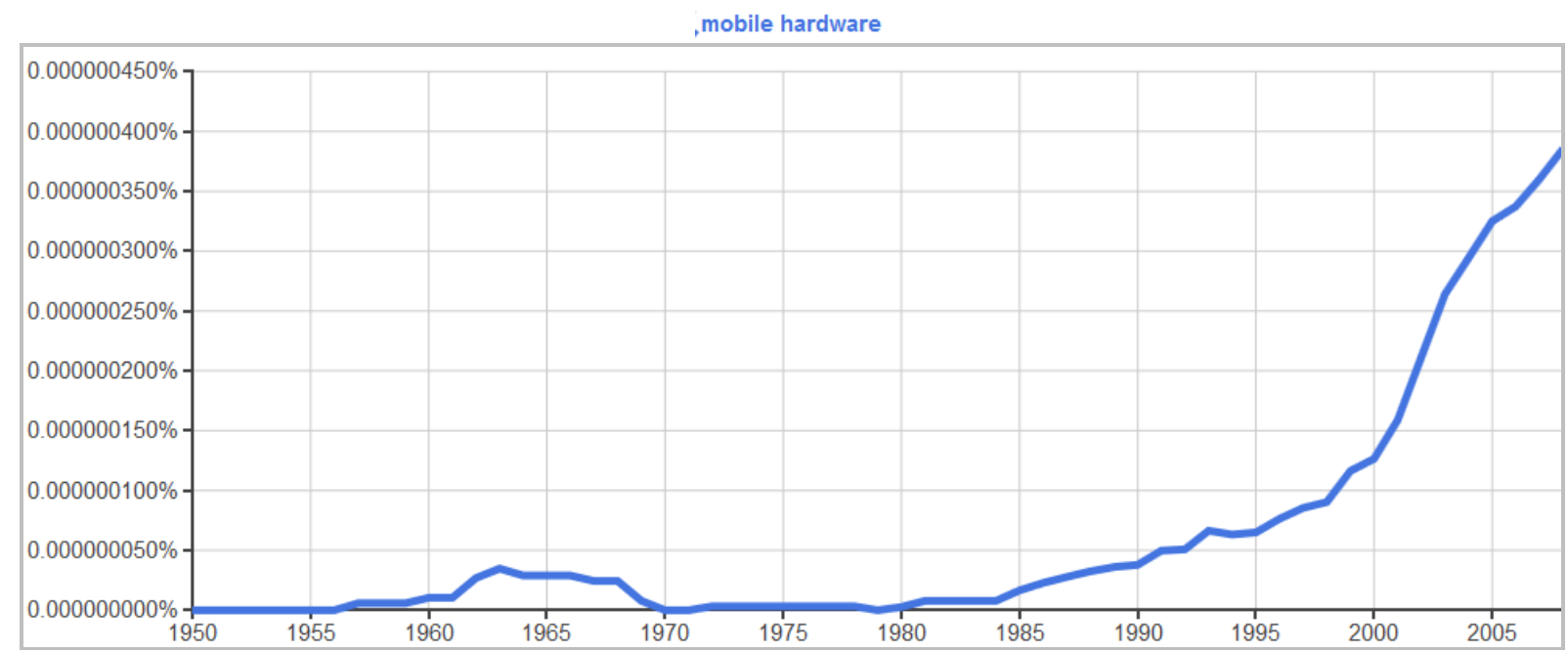

Рис. 9. Мобільність апаратних засобів у англомовних джерелах [16] 
Це пов’язано з різними трактуваннями поняття «мобільний апаратний засіб». У перший період (орієнтовно до 1970 р.) це поняття було пов'язано насамперед із засобами діяльності людини, що могли переміщуватися: транспортні засоби і рухоме обладнання. У другий період (рис. 10) мобільний апаратний засіб трактувався насамперед як мобільний комп'ютерний пристрій (mobile computing device). За визначенням ЮНЕСКО, мобільний пристрій є цифровим, він легко переноситься, як правило, належить і контролюється індивідом, а не установою, може отримати доступ до Інтернету, має мультимедійні можливості, і може сприяти виконанню великої кількості завдань, зокрема, пов'язаних із комунікацією [42, с. 7].

Мобільні комунікації розглядатимемо за Дж. Уррі як четвертий і п’ятий канали реалізації мобільності [44]. Зауважимо, що у поточний момент не будь-яка безпровідна технологія комунікації (наприклад, лазерний зв’язок, квантова телепортація тощо) може використовуватися в мобільних комп'ютерних пристроях.

Ураховуючи, що термін «мобільний комп'ютинг» покриває технології, необхідні людям для доступу до даних і програм через мережу будь-де, надалі визначатимемо його як технологічну мобільність. Ця назва також показує об'єднання двох основних напрямів мобільності - реальної (мобільність фізичних пристроїв) і віртуальної (мобільність програм і даних як віртуальних об’єктів).

Співвідношення видів мобільності в технічних системах у вимірах «реальне віртуальне» подано на рис. 11. Програмна мобільність більше відноситься до віртуального виміру (перенесення програм між різними типами операційних систем i апаратних платформ), проте частково поширена й у реальному (переміщення програм між різними пристроями). Апаратна мобільність, навпаки, більше відноситься до реального виміру (переміщення апаратних засобів у просторі), ніж до віртуального. Мобільні комунікації пов'язані з передаванням віртуальних об'єктів (у найширшому розумінні - інформації) у реальному просторі (безпровідні канали зв'язку).

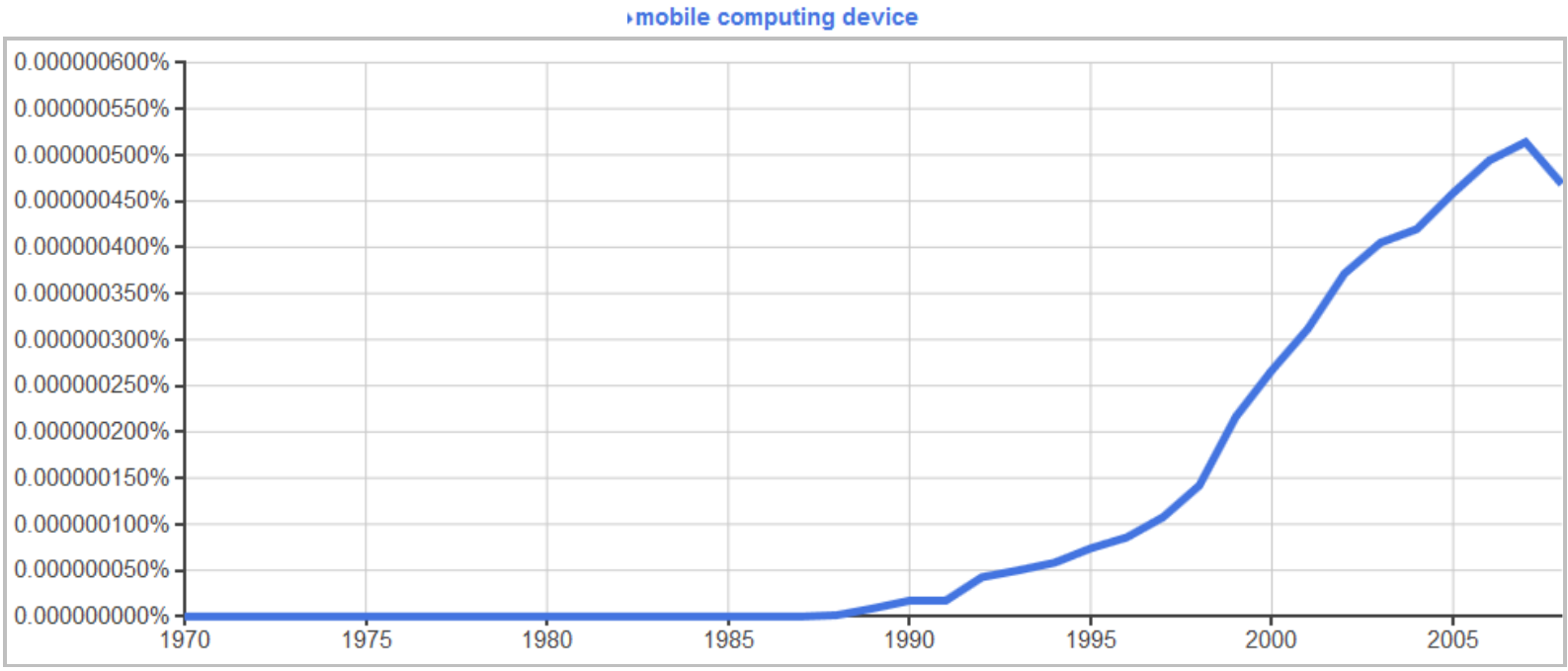

Рис. 10. Мобільність комп'ютерних пристроїв у англомовних джерелах [16] 


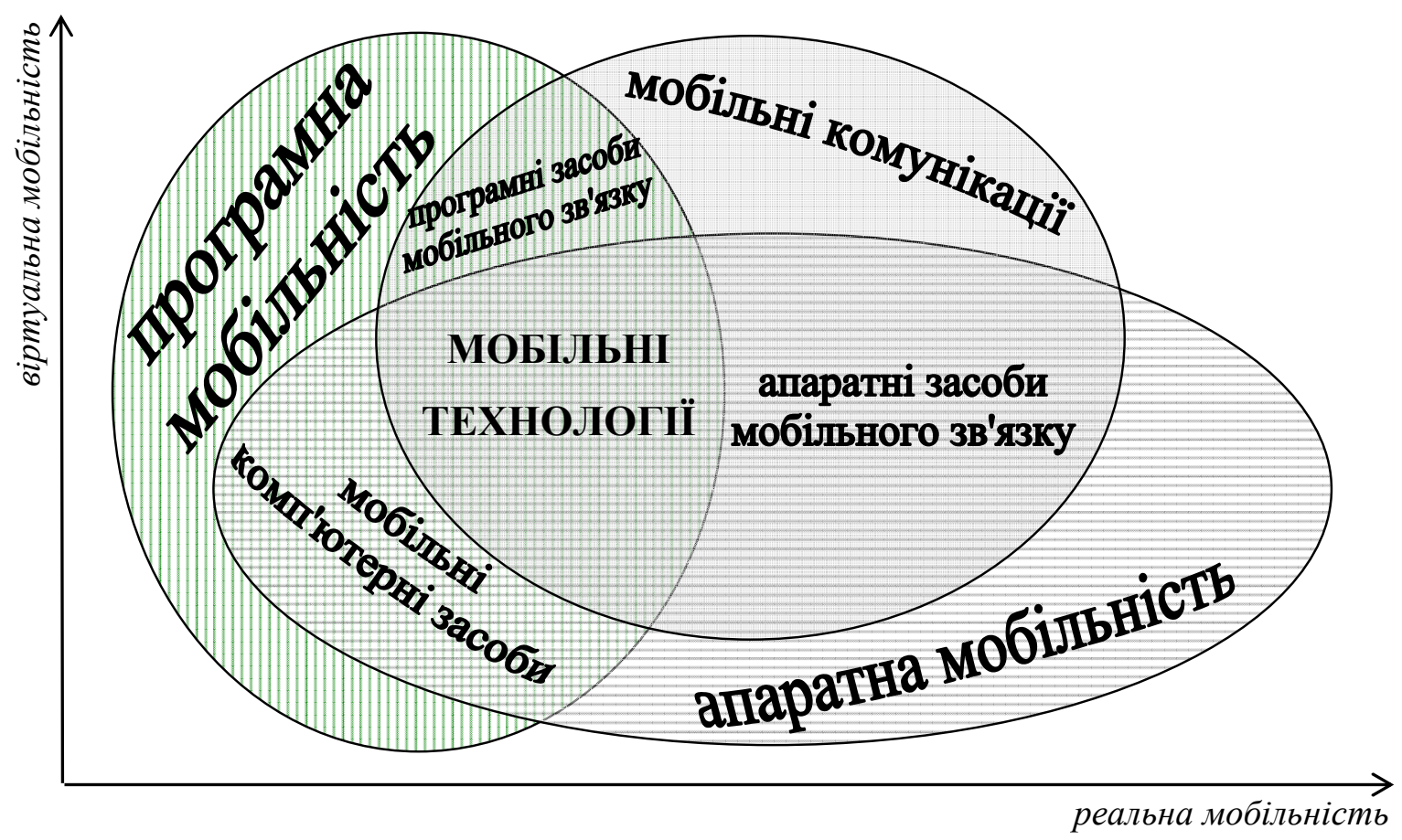

Рис. 11. Співвідношення видів мобільності у технічних системах

Апаратні засоби мобільного зв'язку знаходяться на перетині апаратної мобільності і мобільних комунікацій; програмні засоби мобільного зв'язку - на перетині програмної мобільності й мобільних комунікацій; мобільні комп'ютери - на перетині програмної мобільності й апаратної мобільності. Мобільні технології знаходяться на перетині всіх видів мобільності у технічних системах.

Узагальнення результатів проведеного аналізу генезису і співвідношень вимірів мобільності надало можливість побудувати модель мобільності в інформаційному суспільстві (рис. 12), що має три виміри: один - реальний і два - віртуальні. 


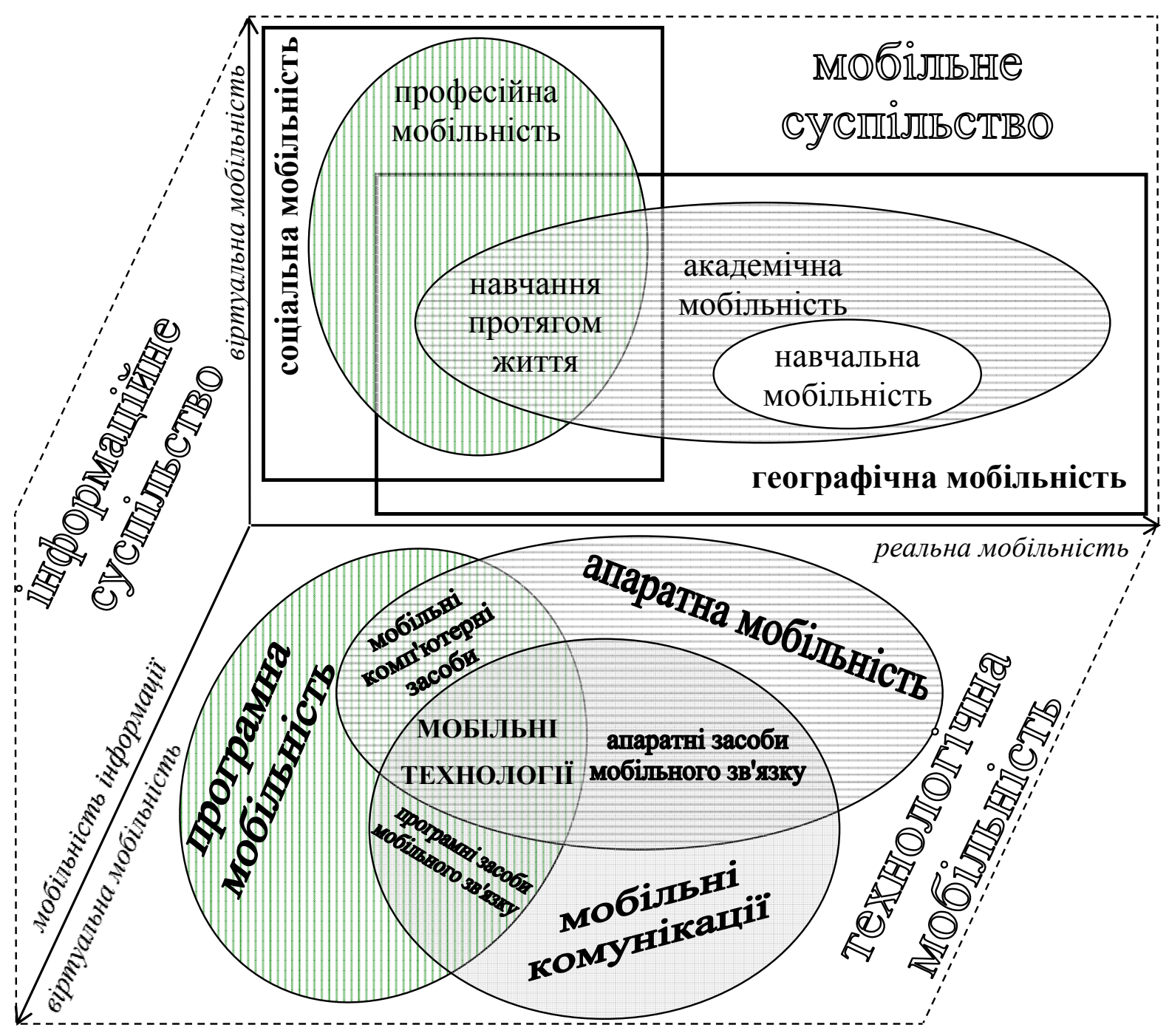

Рис. 12. Модель мобільності в інформаційному суспільстві

Реальний вимір є спільним для соціально-педагогічних і технічних систем у зв'язку з тим, що передбачає вивчення руху у просторі людей (географічна мобільність студентів, фахівців, професіоналів та керівників) і речей (мобільність апаратних засобів IКТ). Перший віртуальний вимір відповідає за соціальну мобільність людей, другий віртуальний вимір - інформаційну мобільність ідей.

Відповідно до запропонованої моделі, реальний і віртуальний виміри мобільності у соціально-педагогічних системах $є$ основою мобільного суспільства, члени якого географічно і соціально мобільні; реальний і віртуальний виміри мобільності у технічних системах - основою технологічної мобільності, а об'єднання обох віртуальних вимірів - інформаційне суспільство, у якому, згідно визначення Комісії Європейських спільнот, основою діяльності людей стають інформаційно-комунікаційні технології [20, с. 92].

\section{3. ВИСНОВКИ ТА ПЕРСПЕКТИВИ ПОДАЛЬШИХ ДОСЛІДЖЕНЬ}

Аналіз першоджерел з проблеми мобільності надав можливість визначити основні етапи еволюції поняття мобільності у науковому дискурсі, виокремити різні види 
мобільності в соціально-педагогічних i технічних системах, запропонувати інтегративну модель мобільності в інформаційному суспільстві.

Поняття мобільності розглянуто як сучасна міждисциплінарна парадигма в соціальних і гуманітарних науках, яка досліджує переміщення людей, ідей і речей, a також наслідки цих рухів. У рамках цієї парадигми виокремлено такі види мобільності, як географічна, соціальна, професійна, академічна, навчальна, програмна, апаратна, технологічна, а також реальна і віртуальна мобільність. Показано, що дослідження у галузі мобільного навчання мають ураховувати системний характер поняття мобільності, не обмежуючись лише окремими ії видами.

Аналіз співвідношення видів мобільності у соціально-педагогічних і технічних системах надав можливість побудувати модель мобільності в інформаційному суспільстві, що має три виміри: один - реальний і два - віртуальні. Реальний вимір $є$ спільним для соціально-педагогічних і технічних систем у зв'язку з тим, що передбачає вивчення руху у просторі людей і речей. Перший віртуальний вимір відповідає за соціальну мобільність людей, другий віртуальний вимір - інформаційну мобільність ідей. Реальний і віртуальний виміри мобільності у соціально-педагогічних системах $\epsilon$ основою мобільного суспільства, члени якого географічно і соціально мобільні; реальний і віртуальний виміри мобільності у технічних системах - основою технологічної мобільності, а об'єднання обох віртуальних вимірів - інформаційне суспільство, у якому основою діяльності людей стають інформаційно-комунікаційні технології.

Відповідно до запропонованої моделі основними напрямами подальших досліджень є:

1) дослідження тенденцій розвитку мобільності у системах вищої освіти як соціокультурного феномену, що постійно еволюціонує взаємозалежно з розвитком технологій, державно-політичними перетвореннями, розвитком соціальних i педагогічних наук;

2) дослідження феномену мобільності в технолого-педагогічних системах, зумовлене поширенням мобільних інформаційно-комунікаційних технологій.

\section{СПИСОК ВИКОРИСТАНИХ ДЖЕРЕЛ}

1. A Dictionary of the Derivations of the English Language. - London and Glasgow : William Collins, Sons, and Company, 1872. $-377 \mathrm{p}$.

2. Achievements of Mobile learning Today [online] / Ana Dias, Desmond Keegan, Gabor Kismihok, Nevena Mileva, Torstein Rekkedal. - 2008. - 178 p. - Available from : http://www.exact.ie/ebook/achievements/ Achievements_of_Mobile_learning_Today.pdf.

3. Auriol L. Careers of Doctorate Holders: Analysis of Labour Market and Mobility Indicators / Laudeline Auriol, Max Misu, Rebecca A. Freeman. - Paris : OECD Publishing, 2013. - 61 p. - (OECD Science, Technology and Industry Working, 2013/04).

4. Avveduto S. Mobility of PhD Students and Scientists / S. Avveduto // International Encyclopedia of Education. Third Edition / Editors-in-Chief Penelope Peterson, Eva Baker, Barry McGaw. - Oxford : Elsevier - Academic Press, 2010. - Volume 4. - P. 286-293.

5. Bartelsen J. Mobile learning - ein Überblick / Jan Bartelsen. - Elmshorn : Nordakad., 2011. - 17 Bl. (Nordakademie (Elmshorn): Arbeitspapiere der Nordakademie ; Nr. 2011,06).

6. Beine M. Brain drain and human capital formation in developing countries: Winners and losers / Michel Beine, Fréderic Docquier and Hillel Rapoport // Economic Journal. - 2008. - Iss. 118. - P. 631-652.

7. Brown W. S. Software portatibility / W. S. Brown // Software engineering techniques : Report on a conference sponsored by the NATO Science Committee. Rome, Italy, 27th to 31st October 1969 / Editors : J. N. Buxton and B. Randell. - Birmingham : The Kynoch Press, April 1970. - P. 80-84.

8. Citizens' summary «Higher education in Europe - modernisation agenda» [online] // European Commission. - [2011]. - 2 p. - Available from : http://ec.europa.eu/education/highereducation/doc/cs_en.pdf.

9. Council Directive 2005/71/EC of 12 October 2005 on a specific procedure for admitting third-country 
nationals for the purposes of scientific // Official Journal of the European Union. - 2005. - Vol. 48. 3 November. - P. 15-22.

10. Davis A. Children of bondage : the personality development of Negro youth in the urban South / Allison Davis, John Dollard. - Washington : American Council on Education, 1940. - XXVIII+299 p.

11. Devine E. T. Report on the desirability of establishing an employment bureau in the city of New York / Edward T. Devine ; Russell Sage Foundation. - New York : Charities Publication Committee, 1909. $238 \mathrm{p}$.

12. Dumont J. C. and Lemaitre, G. Counting immigrants and expatriates in OECD countries: a new perspective [online] / Jean-Christophe Dumont, and Georges Lemaitre ; OECD, Directorate for Employment Labour and Social Affairs. - [Paris] : OECD, [2005]. - Available from : http://www.oecd.org/migration/mig/33868740.pdf - ([OECD Social Employment and Migration Working Papers, N. 25]).

13. Eckpunkte einer Didaktik des mobilen Lernens : Operationalisierung im Rahmen eines Schulversuchs [Elektronische Ressource] / Ben Bachmair, Maren Risch, Katja Friedrich und Katja Mayer // Themenheft Nr. 19: Mobile Learning in Widening Contexts: Concepts and Cases. - 11. März 2011. - 38 p. - AccessModus : http://www.medienpaed.com/19/bachmair1103.pdf.

14. Educating Children with Physical Disabilities / Z. P. Nkabinde, F. E. Obiakor, M. T. Offor, D. J. Smith // International Encyclopedia of Education. Third Edition / Editors-in-Chief Penelope Peterson, Eva Baker, Barry McGaw. - Oxford : Elsevier - Academic Press, 2010. - Volume 2. - P. 640-645.

15. Emigration of Scientists from the United Kingdom : Report of a Committee Appointed by the Council of the Royal Society. - London : Royal Society, 1963. - 32 p.

16. Google books Ngram Viewer [online] / Google. - 2012. - Available from : http://books.google.com/ngrams.

17. Google Project Glass: User-friendly Tool / Editor : Edward R. Miller-Jones. - FastBook Publishing, 2013. $-140 \mathrm{p}$.

18. Gordon E. Net Locality: Why Location Matters in a Networked World / Eric Gordon, Adriana de Souza e Silva. - Hoboken : Wiley-Blackwell, 2011. - 200 p.

19. Green Paper : The European Research Area: New Perspectives [online] / Commission of the European Communities. - Brussels, 2007. - 23 p. - Available from : http://ec.europa.eu/research/era/pdf/era_gp_final_en.pdf.

20. Growth, competitiveness, employment - The challenges and ways forward into the 21st century (White Paper). Parts A and B. COM (93) 700. - Luxembourg : Office for Official Publications of the European Communities, 1993. - 151 p. - (Bulletin of the European Communities, Supplement 6/93).

21. Higher Education in Virtual Worlds: Teaching and Learning in Second Life / Edited by Charles Wankel, Jan Kingsley. - Bingley : Emerald Group Publishing, 2009. - 256 p.

22. Humboldt A. von. Cosmos : A Sketch of a Physical Description of the Universe / Alexander von Humboldt. - Vol. II. - London : Henry G. Bohn, 1849. - 422 p.

23. Keegan D. The future of learning: From eLearning to mLearning / Desmond Keegan.-Hagen : Fernuniv., GHS, 2002. - 172 S. - (ZIFF Papiere. 119)

24. Knight J. Crossborder Education: An Analytical Framework for Program and Provider Mobility / Jane Knight // Higher Education: Handbook of Theory and Research. Volume XXI / Edited by John C. Smart. - Dordrecht : Springer, 2006. - P. 345-395.

25. Knight J. Higher Education Crossing Borders / J. Knight // International Encyclopedia of Education. Third Edition / Editors-in-Chief Penelope Peterson, Eva Baker, Barry McGaw. - Oxford : Elsevier Academic Press, 2010. - Volume 4. - P. 507-513.

26. Ko E. The Washington Accord on Engineering Curriculum / E. Ko // International Encyclopedia of Education. Third Edition / Editors-in-Chief Penelope Peterson, Eva Baker, Barry McGaw. - Oxford : Elsevier - Academic Press, 2010. - Volume 4. - P. 209-215.

27. Köhler M. Rapid (Mobile) E-Learning-Content-Development : Konzeption und Entwicklung des RapidE-Learning-Content-Development-Tools "FLOG" (Flash Learning Objects Generator) zur Erstellung und Verwaltung von wiederverwendbaren Lernobjekten für mobile Endgeräte und PCs : Inauguraldissertation zur Erlangung des Doktorgrades der Humanwissenschaftlichen Fakultät der Universität zu Köln nach der Promotionsordnung vom 12.07.2007 / Michael Köhler. - Köln, 2009. - IX+172 S.

28. Kuszpa M. Mobile Learning - Modetrend oder wesentlicher Bestandteil lebenslangen Lernens? / Maciej Kuszpa und Ewald Scherm. - Hagen : Fachbereich Wirtschaftswissenschaft der FernUniversität in Hagen, 2005. - 30 S. - (Diskussionsbeitraege / Fachbereich Wirtschaftswissenschaft, FernUniversitaet in Hagen. 380)

29. Lachtman S. A. Racial Inequality and the Economic Payoffs of Higher Education / S. A. Lachtman // International Encyclopedia of Education. Third Edition / Editors-in-Chief Penelope Peterson, Eva Baker, Barry McGaw. - Oxford : Elsevier - Academic Press, 2010. - Volume 1. - P. 542-546. 
30. MOTILL : Mobile Technologies in Lifelong Learning/Best practices / Edited by M. Arrigo, O. Di Giuseppe, G. Fulantelli, M. Gentile, G. Merlo, L. Seta, D. Taibi. - Palermo : Eurografica s.r.1, [2010]. $63 \mathrm{p}$.

31. Obi S. O. Related Services for Children with Special Needs / S. O. Obi // International Encyclopedia of Education. Third Edition / Editors-in-Chief Penelope Peterson, Eva Baker, Barry McGaw. - Oxford : Elsevier - Academic Press, 2010. - Volume 2. - P. 834-839.

32. Proceedings of the International Congress on Technology and Blindness : Volume III: Panel III, Sound recording and reproduction. Panel IV, Adapted and special purpose devices, 2d ed. / Edited by Leslie L. Clark. - New York : American Foundation for the Blind, 1963. - 384 p.

33. Shah C. Skills Shortages: Concepts, Measurement and Policy Responses / C. Shah and G. Burke // International Encyclopedia of Education. Third Edition / Editors-in-Chief Penelope Peterson, Eva Baker, Barry McGaw. - Oxford : Elsevier - Academic Press, 2010. - Volume 8. - P. 320-327.

34. Sheller M. Mobility [online] / Mimi Sheller // sociopedia.isa. - 2011. - 12 p. - Available from : http://www.sagepub.net/isa/resources/pdf/Mobility.pdf

35. Special Features in City School Systems / United States Bureau of Education. - Washington : Govt. Print. Off., 1913. - (Statistics of land-grant colleges and universities, Vol. 3, Issues 31-45).

36. Study on Mobility Developments in School Education, Vocational Education and Training, Adult Education and Youth Exchanges [online] / European Commission. - June 2012. - 418 p. - Available from : http://ec.europa.eu/education/documents/more-information/mobility-study-report.pdf

37. The EU and the Bologna Process - shared goals, shared commitments : Supporting growth and jobs - An agenda for the modernisation of Europe's higher education systems / European Commission. Luxembourg : Publications Office of the European Union, 2012. - 32 p.

38. The genesis and development of mobile learning in Europe / Agnes Kukulska-Hulme, Mike Sharples, Marcelo Milrad, Inmaculada Arnedillo-Sánchez, Giasemi Vavoula // Combining E-Learning and MLearning: New Applications of Blended Educational Resources / Ed. : David Parsons. - Hershey : IGI Global, 2011. - P. 151-177.

39. The Role of Mobile Learning in Europe Today [online] / José Carvalho, Ignacio Carril, Ana Dias, Zsolt Ispán, Jim Jack, Desmond Keegan, Gabor Kismihók, Nevena Mileva, Morten Flate Paulsen, Torstein Rekkedal, Bernadette Simpson. - 2008. - 306 p. - Available from : http://www.exact.ie/ebook/mobilelearning/The_Role_of_Mobile_learning_in_Europe_Today.pdf.

40. Traxler J. Context in a Wider Context [Elektronische Ressource] / John Traxler // Themenheft Nr. 19: Mobile Learning in Widening Contexts: Concepts and Cases. - 8. Juli 2011. - 16 p. - Access-Modus : http://www.medienpaed.com/19/traxler1107.pdf.

41. Traxler J. Current State of Mobile Learning / John Traxler // Mobile Learning : Transforming the Delivery of Education and Training / Edited by Mohamed Ally. - Edmonton : Athabasca University Press, 2009. - P. 9-24.

42. UNESCO policy guidelines for mobile learning [online] / Edited by Rebecca Kraut. - Paris : UNESCO, 2013. - 41, [1] p. - Available from : http://unesdoc.unesco.org/images/0021/002196/219641E.pdf

43. Urry J. Climate change, travel and complex futures / John Urry // The British Journal of Sociology. 2008. - Volume 59, Issue 2. - P. 261-279.

44. Urry J. Sociology Beyond Societies: Mobilities for the Twenty-first Century / John Urry. - London : Routledge, 2000. - 255 p. - (International Library of Sociology).

45. Wende M. van der. Internationalization of Higher Education / M. van der Wende // International Encyclopedia of Education. Third Edition / Editors-in-Chief Penelope Peterson, Eva Baker, Barry McGaw. - Oxford : Elsevier - Academic Press, 2010. - Volume 4. - P. 540-545.

46. Zare S. Intelligent Mobile Learning Interaction System (IMLIS) : A Personalized Learning System for People with Mental Disabilities : Doctoral Thesis is submitted ... in fulfillment of the degree of Doctor of Engineering / Saeed Zare ; University of Bremen. - Bremen, 2010. - XX+263 p.

47. Аніщенко В. М. Професійна мобільність / В. М. Аніщенко // Енциклопедія освіти / Академія педагогічних наук України ; головний редактор академік НАН і АПН України, Президент АПН України В. Г. Кремень. - К. : Юрінком Інтер, 2008. - С. 725.

48. Аніщенко В. М. Соціальна мобільність / В. М. Аніщенко // Енциклопедія освіти / Академія педагогічних наук України ; головний редактор академік НАН і АПН України, Президент АПН України В. Г. Кремень. - К. : Юрінком Інтер, 2008. - С. 840.

49. Балыхин М. Г. Тенденции развития международного рынка образовательных услуг : на примере стран Евросоюза и Российской Федерации : дис. ... кандидата экономических наук : 08.00.14 мировая экономика / Балыхин Михаил Григорьевич ; Министерство образования и науки Российской Федерации, Российский университет дружбы народов. - М., 2009. - 174 с.

50. Велика Хартія Університетів [Електронний ресурс] - Болонья, 18 вересня 1988. - Режим доступу : http://www.magna-charta.org/magna.html. 
51. Великий тлумачний словник сучасної української мови (з дод. і допов.) / Уклад. і голов. ред. В. Т. Бусел. - К. ; Ірпінь : Перун, 2005. - 1728 с.

52. Гаманюк В. А. E-learning, M-learning, Blended Learning і дистанційне навчання у системі іншомовної освіти Німеччини / Віта Гаманюк // Педагогіка і психологія професійної освіти. 2012. - №2. - С. 211-220.

53. Грачева В. Г. Развитие высшего педагогического образования в Западной Европе на современном этапе : дис. ... канд. пед. наук : 13.00.01 «Общая педагогика, история педагогики и образования» / Грачева Валерия Геннадьевна ; Волгоградский государственный педагогический университет. Волгоград, 2007. - 186 с.

54. Григорьева М. А. Деятельностный подход в обучении школьников информатике с использованием мобильных компьютерных систем : автореферат дис. ... кандидата педагогических наук : 13.00.02 «Теория и методика обучения и воспитания (информатика)» / Григорьева Марина Александровна ; [Место защиты : Моск. гор. пед. ун-т]. - М., 2011. - 24 с.

55. Д'юї Дж. Демократія і освіта / Джон Д'юї ; пер. з англ. І. Босак, М. Олійник, Г. Пехник. - Львів : Літопис, 2003. - 294 с.

56. Дем’яненко Н. М. Тенденції диверсифікації мети і профілів магістратури в розвитку світової вищої освіти / Наталія Дем'яненко // Педагогічні науки : збірник наукових праць. Вип. 2 / Полтавський нац. пед. ун-т ім. В. Г. Короленка ; голов. ред. М. Степаненко. - Полтава : [б. в.], 2010. - C. 44-52.

57. Десятов Т. М. Тенденції розвитку неперервної освіти в країнах Східної Свропи (друга половина XX століття) : автореф. дис. ... д-ра пед. наук : 13.00.01 «Загальна педагогіка та історія педагогіки» / Десятов Тимофій Михайлович ; Інститут педагогіки Академії педагогічних наук України. - К., 2006. -35 c.

58. Дударь 3. В. Модели и методы мобильного дистанционного обучения / 3. В. Дударь, Д. Н. Колесник // Восточно-Европейский журнал передовых технологий. - 2008. - 3/2 (33) - С. 51-54.

59. Жуков О. В. Применение компьютерно-мобильной системы в процессе подготовки педагогов профессионального обучения : автореферат дис. ... кандидата педагогических наук : 13.00.08 «Теория и методика профессионального образования» / Жуков Олег Викторович ; [Место защиты : Рос. междунар. акад. туризма]. - М., 2008. - 20 с.

60. Заскалєта С. Г. Модернізація професійної підготовки фахівців аграрної галузі в країнах ЄС / Світлана Заскалєта // Порівняльно-педагогічні студії. - 2011. - №2(8). - С. 42-47.

61. Иванова В. И. Единое образовательное пространство как фактор инновационного развития экономики Европейского Союза : автореферат дис. ... кандидата экономических наук : 08.00.14 «Мировая экономика» / Иванова Валерия Ивановна ; Государственный университет управления. M., 2012. -24 c.

62. Калуга Т. А. Мобильное обучение в дистанционном образовании / Т. А. Калуга // Вісник ЛНУ імені Тараса Шевченка. - 2011. - № 12 (223), червень. - Ч. І. - С. 113-124.

63. Кашлачева Т. С. Интеграция европейского и российского высшего образования: институциональный аспект : автореферат диссертации ... кандидата социологических наук : 22.00.04 - социальная структура, социальные институты и процессы / Кашлачева Татьяна Сергеевна ; Санкт-Петербургский государственный университет. - Санкт-Петербург, 2007. - 20 с.

64. Кирда А. Г. Тенденції розвитку цілей освіти в розвинених країнах світу і Україні (друга половина XX століття) : автореф. дис. ... канд. пед. наук : 13.00.01 «Загальна педагогіка та історія педагогіки» / Кирда Алла Григорівна ; Київський національний університет імені Тараса Шевченка. - К., 2005. - 26 с.

65. Козак Т. М. Організаційно-педагогічні засади впровадження кредитно-модульної системи підготовки фахівців у вищих педагогічних навчальних закладах III-IV рівнів акредитації : автореф. дис. ... канд. пед. наук : 13.00.01 «Загальна педагогіка та історія педагогіки» / Козак Тетяна Михайлівна ; Житомирський державний університет імені Івана Франка. - Житомир, 2007-19 с.

66. Козяр М. М. Застосування технологій гаджетів та віджетів у навчанні / М. М. Козяр, А. Д. Кузик // Вісник Львівського державного університету безпеки життєдіяльності : збірник наукових праць. Львів, 2008. - №2. - С. 7-15.

67. Компьютерная технология обучения : словарь-справочник / под редакцией Гриценко В. И., Довгялло А. М., Савельева А. Я. - К. : Наукова думка, 1992. - 650 с.

68. Корсак К. В. Соціально-філософський аналіз тенденцій розвитку тріади «людина-суспільствоосвіта» на початку XXI століття : дис. ... д-ра філос. наук : 09.00.10 «Філософія освіти» / Корсак Костянтин Віталійович ; АПН України, Інститут вищої освіти. - К., 2006. - 461 арк.

69. Кряжев П. В. Тенденції реформування вищої освіти у країнах Західної Європи : автореф. дис. ... канд пед. наук : 13.00.01 «Загальна педагогіка та історія педагогіки» / Кряжев Павло Володимирович ; Інститут вищої освіти Академії педагогічних наук України. - К., 2007. - 20 с. 
70. Кувшинов С. В. M-learning - новая реальность образования / С. Кувшинов // Высшее образование в России. - 2007. - № 8. - С. 75-78.

71. Кугель С. А. Записки социолога / С. А. Кугель. - СПб. : Нестор-История, 2005. - 204 с.

72. Кудря М. М. Процеси і тенденції розвитку вищої освітив Свропі до кінця 90-х років і етапи передісторії Болонського процесу / Микола Кудря // Гуманітарний вісник ДВНЗ «ПереяславХмельницький державний педагогічний університет імені Григорія Сковороди» : науковотеоретичний збірник. Педагогіка. Психологія. Філософія. - 2008. - Вип. 16. - С. 115-120.

73. Куклев В. А. Становление системы мобильного обучения в открытом дистанционном образовании : дисс. ... д-ра пед. наук : 13.00.01 «Общая педагогика, история педагогики и образования» / Куклев Валерий Александрович ; Ульяновский государственный технический университет. - Ульяновск, 2010. - 515 c.

74. Курс дистанционного обучения «Неопределенность результата измерения» с использованием мобильных технологий / В. Д. Циделко, Н. А. Яремчук, М. В. Галёвская, В. В. Бабин // Системи обробки інформації. - Випуск 4 (71). - 2008. - С. 148-150.

75. Лавриченко Н. М. Європа освіти і порівняльна педагогіка в їх обопільному поступі / Наталія Лавриченко // Порівняльно-педагогічні студії. - 2009. - №1. - С. 10-17.

76. Лазарева Л. А. Проблемы формирования единого европейского пространства высшего образования (вторая половина XX века - начало XXI века) : дис. ... кандидата исторических наук : 07.00.03 - всеобщая история / Лазарева Лилия Александровна ; Ростовский государственный университет. - Ростов-на-Дону, 2006. - 242 с.

77. Локшина О. І. Тенденція як категорія порівняльної педагогіки / Олена Локшина // Порівняльнопедагогічні студії. - 2011. - №2(8). - С. 5-14.

78. Лубіна Є. Мобільне навчання у дидактиці вищої школи / Єва Лубіна // Вісник Львівського університету. Серія Педагогічна. - Львів, 2009. - Вип. 25, Ч. 2. - С. 61-66.

79. Любченко В. В. Метод будування навчальної траєкторії в умовах мобільного навчання / В. В. Любченко, О. С. Шинкарюк // Вісник Національного технічного університету «Харківський політехнічний інститут» : збірник наукових праць. Тематичний випуск : Інформатика i моделювання. - 2011. - №17. - С. 81-85.

80. Маклакова Е. В. Историко-педагогические подходы к оценке эффективности образовательных процессов в университетах Западной Европы : автореферат дис. ... доктора педагогических наук : 13.00.01 / Маклакова Елена Владимировна ; Институт содержания и методов обучения Российской академии образования. - М., 2009. - 35 с.

81. Мартынова О. В. Подготовка учителей в Германии в условиях создания европейского пространства высшего образования : дис. ... канд. пед. наук : 13.00.01 «Общая педагогика, история педагогики и образования» / Мартынова Ольга Владимировна ; Пензенский государственный педагогический университет им. В. Г. Белинского. - Пенза, 2006. - 180 с.

82. Михалкина Е. Г. Компьютерно-мобильные технологии как средство повышения качества профессиональной подготовки будущих менеджеров : диссертация ... кандидата педагогических наук : 13.00.08 «Теория и методика профессионального образования» / Михалкина Евгения Германовна ; Министерство образования и науки Российской Федерации, Московский государственный индустриальный университет (ГОУ ВПО МГИУ). - М., 2009. - 245 с.

83. Мотін М. М. Класифікація систем мобільного навчання / М(он). М. Мотін // ВосточноЕвропейский журнал передовых технологий. - Харьков : Технологический центр, 2011. - №1/2 (49). - С. 30-33.

84. Мошляк Г. А. Исторический опыт реализации основных направлений сотрудничества России и европейских стран в области высшего образования в 1999-2009 гг. : автореферат дис. ... кандидата исторических наук : 07.00.02 «Отечественная история» / Мошляк Габриэль Алексеевна ; Российский университет дружбы народов. - М., 2012. - 28 с.

85. Негребецкая Н. В. Основные тенденции развития высшего педагогического образования стран Западной Европы конца 20 века (на материале Англии, Франции, Германии) : диссертация ... кандидата педагогических наук : 13.00 .08 «Теория и методика профессионального образования» / Негребецкая Наталья Викторовна ; Белгородский государственный университет. - Белгород, 2003. $-150 \mathrm{c}$.

86. Немец Л. Н. Устойчивое развитие: социально-географические аспекты (на примере Украины) : монография / Людмила Николаевна Немец. - Харьков : Факт, 2003. - 383 с.

87. Онищенко Л. В. Высшая техническая школа Франции в контексте построения единого европейского образовательного пространства : автореферат диссертации ... кандидата педагогических наук : 13.00.01 «Общая педагогика, история педагогики и образования» / Онищенко, Лилия Валентиновна ; Институт педагогики и психологии профессионального образования Российской академии образования. - Казань, 2011. - 22 с. 
88. Осадчий В. В. Теорія і практика організації мобільної технології навчання у педагогічному університеті / В. В. Осадчий // Педагогічний дискурс : збірник наукових праць / Інститут педагогіки Академії педагогічних наук України, Хмельницька гуманітарно-педагогічна академія. Хмельницький, 2011. - Випуск 9. - С. 258-263.

89. Поберезська Г. Г. Тенденції розвитку вищої освіти країн Західної Свропи та України : автореф. дис. ... канд пед. наук : 13.00.01 «Загальна педагогіка та історія педагогіки» / Поберезська Ганна Георгіївна ; Інститут вищої освіти Академії педагогічних наук України. -К., 2005. - 22 с.

90. Поживілова О. В. Розвиток систем підготовки наукових і науково-педагогічних кадрів вищої кваліфікації в європейському регіоні та Україні (1990-2005 рр.) : дис. ... канд. пед. наук : 13.00 .01 «Загальна педагогіка та історія педагогіки» / Поживілова Олена Володимирівна ; Інститут вищої освіти Академії педагогічних наук України. - К., 2006. - 181 с.

91. Полунина Л. Н. Подготовка учителей в европейских странах: национальные приоритеты и интеграция в контексте Болонского процесса : диссертация ... кандидата педагогических наук : 13.00.01 «Общая педагогика, история педагогики и образования» / Полунина Людмила Николаевна ; Федеральное агентство по образованию, ГОУ ВПО «Тульский государственный университет им. Л. Н. Толстого». - Тула, 2006. - 202 с.

92. Постова Л. С. Нові тенденції розвитку вищої освіти в умовах європейського контексту / Постова Л. С. // Наукові праці. Педагогіка. Том VII. - [Миколаїв], 2000. - С. 49-50.

93. Про Національну стратегію розвитку освіти в Україні на період до 2021 року : Указ № 344/2013 від 25.06.2013 [Електронний ресурс] / Президент України. - Режим доступу : http://www.president.gov.ua/documents/15828.html.

94. Рашевська Н. В. Технологічні умови реалізації мобільного навчання у вищій школі / Н. В. Рашевська // Вісник Черкаського університету. - Черкаси, 2011. - Випуск 201. Частина I. - С. 100-104.

95. Рыжова Н. А. Интеграция российского библиотечно-информационного образования в Болонский процесс: содержательные и организационные аспекты : дис. ... кандидата педагогических наук : 05.25.03 «Библиотековедение, библиографоведение и книговедение» / Наталия Анатольевна Рыжова ; ФГОУ ВПО «Орловский государственный институт искусств и культуры». - Орел, 2008. $-236 \mathrm{c}$.

96. Сбруєва А. А. Глобальні та регіональні тенденції розвитку вищої освіти в умовах побудови суспільства знань : препринт / А. А. Сбруєва. - Суми : СумДПУ ім. А. С. Макаренка, 2008. - 80 с.

97. Семеріков С. О. Мобільне навчання: історія, теорія, методика / С. Семеріков, І. Теплицький, С. Шокалюк // Інформатика та інформаційні технології в навчальних закладах. - 2008. - №6. C. $72-82 ; 2009$. - №1. - C. 96-104.

98. Семеріков С. О. Фундаменталізація навчання інформатичних дисциплін у вищій школі : монографія / Семеріков С. О. ; науковий редактор академік АПН України, д. пед. н., проф. М. I. Жалдак. - Кривий Ріг : Мінерал; К. : НПУ ім. М. П. Драгоманова, 2009. - 340 с.

99. Словак К. І. Методика використання мобільних математичних середовищ у процесі навчання вищої математики студентів економічних спеціальностей : дисертація ... кандидата педагогічних наук : 13.00.10 «Інформаційно-комунікаційні технології в освіті» / Словак Катерина Іванівна ; Інститут інформаційних технологій і засобів навчання Національної академії педагогічних наук України. - 291 с.

100. Стрюк М. І. Навчальний об’єкт як компонент мобільного навчання / М. І. Стрюк, А. М. Стрюк // Збірник наукових праць Кам’янець-Подільського національного університету. Серія педагогічна / [редкол. : П. С. Атаманчук (голова, наук. ред.) та ін.]. - Кам'янець-Подільський : Кам'янецьПодільський національний університет імені Івана Огієнка, 2012. - Вип. 18 : Інновації в навчанні фізики: національний та міжнародний досвід. - С. 83-86.

101. Сушенцева Л. Л. Формування професійної мобільності майбутніх кваліфікованих робітників у професійно-технічних навчальних закладах: теорія і практика : монографія / Лілія Леонідівна Сушенцева ; за ред. Н. Г. Ничкало ; Інститут професійно-технічної освіти НАПН України. Кривий Ріг : Видавничий дім, 2011. - 439 с.

102. Теплицький I. О. Модель мобільного навчання в середній та вищій школі / I. О. Теплицький, С. О. Семеріков, О. П. Поліщук // Комп'ютерне моделювання в освіті : матеріали III Всеукраїнського науково-методичного семінару. - Кривий Ріг, 24 квітня 2008 р. - Кривий Ріг : КДПУ, 2008. - С. 45-46.

103. Триус Ю. В. Інноваційні інформаційні технології у навчанні математичних дисциплін / Ю. В. Триус // Вісник Національного університету «Львівська політехніка». Серія: Інформатизація вищого навчального закладу / Міністерство освіти i науки, молоді та спорту України, Національний університет «Львівська політехніка». - Львів : Видавництво Львівської політехнік, 2012. - №731. -C. 76-81. 
104. Тряпицын А. В. Моделирование подготовки школьных администраторов в контексте европейских образовательных процессов : диссертация ... доктора педагогических наук : 13.00 .08 «Теория и методика профессионального образования» / Тряпицын Александр Вячеславович ; СанктПетербургская академия постдипломного педагогического образования. - Санкт-Петербург, 2005. -479 c.

105. Тысячнюк М. С. Мобильная социология Джона Урри / М. С. Тысячнюк // Журнал социологии и социальной антропологии. - 2004. - Том VII. - №4. - С. 200-208.

106. Филатова Н. С. Философские основания модели образовательного пространства : Болонский сценарий развития : автореферат дис. ... кандидата философских наук : 09.00.11 «Социальная философия» / Филатова Наталья Степановна ; Чувашский государственный университет им. И. Н. Ульянова. - Чебоксары, 2007. - 22 с.

107. Хоменко Л. Г. История отечественной кибернетики и информатики : монография / Хоменко Л. Г. К. : Ин-т кибернетики им. В.М. Глушкова НАН Украины, 1998. - 455 с.

108. Чистохвалов В. Н. Формирование и реализация интеграционных образовательных процессов в Российской Федерации и в Европейском Союзе в 1991-2005 годах: сравнительный анализ, опыт, проблемы и перспективы : автореферат диссертации ... доктора исторических наук : 07.00.02 «Отечественная история» / Чистохвалов Виктор Николаевич ; Российский университет дружбы народов. - М., 2010. - 51 c.

109. Шуневич Б. І. Розвиток дистанційного навчання у вищій школі країн Європи та Північної Америки : автореф. дис. ... д-ра пед. наук : 13.00.01 «Загальна педагогіка та історія педагогіки» / Шуневич Богдан Іванович ; Інститут вищої освіти Академії педагогічних наук України. - К., 2008. $-36 \mathrm{c}$.

Матеріал надійшов до редакиї 11.08.2015 p.

\section{МОБИЛЬНОСТЬ: СИСТЕМНЫЙ ПОДХОД}

\section{Стрюк Николай Иванович}

доцент, кандидат исторических наук,

проректор по научно-педагогической и учебно-воспитательной работе

Государственное высшее учебное заведение «Криворожский национальный университет»,

г. Кривой Рог, Украина

stryukm@gmail.com

\section{Семериков Сергей Алексеевич}

профессор, доктор педагогических наук,

заведующий кафедрой фундаментальных и социально-гуманитарных дисциплин

Государственное высшее учебное заведение «Криворожский национальный университет»,

г. Кривой Рог, Украина

semerikov@gmail.com

\section{Стрюк Андрей Николаевич}

доцент, кандидат педагогических наук, докторант

Институт информационных технологий и средств обучения НАПН Украины, г. Киев, Украина

andrey.n.stryuk@gmail.com

Аннотация. В статье проведено комплексное исследование проблемы мобильности в социально-педагогических и технических системах: проанализирована эволюция понятия мобильности в научных источниках XIX-XXI веков и введены в научный оборот новые первоисточники по проблеме мобильности, теоретически обосновано соотношение видов мобильности в социально-педагогических и технических системах, предложена интегративная модель мобильности в информационном обществе. Выделены основные тенденции развития академической мобильности (переход от мобильности студентов к мобильности программ и поставщиков образовательных услуг) и охарактеризованы новые программы мобильности (франчайзинг, двойные/совместные степени, соединение, нострификация и т. п.). Рассмотрены новые виды поставщиков мобильности и акцентировано внимание на виртуальных университетах, являющихся сегодня основой виртуальной мобильности студентов, деятельность которых основана на использовании новых ИКТ в высшем образовании, в первую очередь - Интернет и мобильных учебных сред. 
Ключевые слова: реальная мобильность; виртуальная мобильность; географическая мобильность; социальная мобильность; профессиональная мобильность; академическая мобильность; учебная мобильность; программная мобильность; аппаратная мобильность; технологическая мобильность; мобильные коммуникации; мобильное общество; информационное общество.

\title{
MOBILITY: A SYSTEMS APPROACH
}

\author{
Mykola I. Striuk \\ Associate Professor, Ph. D. (history), vice-rector on scientific-pedagogical and educational work \\ State institution of higher education «Kryvyi Rih National University», Kryvyi Rih, Ukraine \\ stryukm@gmail.com
}

\section{Serhiy O. Semerikov}

Full Professor, D. Sc. (pedagogical sciences), head of Fundamental and Socio-humanitarian Disciplines Department

State Institution of Higher Education «Kryvyi Rih National University», Kryvyi Rih, Ukraine semerikov@gmail.com

\section{Andrii M. Striuk}

Associate Professor, Ph. D. (pedagogical sciences), doctorate student Institute of Information Technologies and Learning Tools of NAES of Ukraine, Kyiv, Ukraine andrey.n.stryuk@gmail.com

\begin{abstract}
A comprehensive study on the problem of mobility in the socio-educational and technical systems was carried out: the evolution of the concept of mobility in scientific sources of XIX-XXI centuries was analyzed and the new sources on the issue of mobility introduced into scientific circulation, the interrelation of the types of mobility in the socio-pedagogical and technical systems are theoretically grounded, an integrative model of mobility in the information society is proposed. The major trends in academic mobility are identified (the transition from student mobility to mobility programs and educational services providers), the new mobility programs (franchising, double/joint degrees, combinations, nostrification etc.) are characterized. The new types of mobility providers are reviewed and attention is focused on virtual universities that are now the basis of virtual mobility of students and activities which are based on the use of new ICT in higher education, especially - the Internet and mobile learning environments.
\end{abstract}

Keywords: real mobility; virtual mobility; geographical mobility; social mobility; professional mobility; academic mobility; learning mobility; software portatibility; hardware mobility; technological mobility; mobile communications; mobile society; information society.

\section{REFERENCES (TRANSLATED AND TRANSLITERATED)}

1. A Dictionary of the Derivations of the English Language. - London and Glasgow : William Collins, Sons, and Company, 1872. - 377 p. (in English).

2. Achievements of Mobile learning Today [online] / Ana Dias, Desmond Keegan, Gabor Kismihok, Nevena Mileva, Torstein Rekkedal. - 2008. - 178 p. - Available from : http://www.exact.ie/ebook/achievements/ Achievements_of_Mobile_learning_Today.pdf (in English).

3. Auriol L. Careers of Doctorate Holders: Analysis of Labour Market and Mobility Indicators / Laudeline Auriol, Max Misu, Rebecca A. Freeman. - Paris : OECD Publishing, 2013. - 61 p. - (OECD Science, Technology and Industry Working, 2013/04) (in English).

4. Avveduto S. Mobility of PhD Students and Scientists / S. Avveduto // International Encyclopedia of Education. Third Edition / Editors-in-Chief Penelope Peterson, Eva Baker, Barry McGaw. - Oxford : Elsevier - Academic Press, 2010. - Volume 4. - P. 286-293 (in English).

5. Bartelsen J. Mobile learning - ein Überblick / Jan Bartelsen. - Elmshorn : Nordakad., 2011. - 17 B1. (Nordakademie (Elmshorn): Arbeitspapiere der Nordakademie ; Nr. 2011,06) (in German).

6. Beine M. Brain drain and human capital formation in developing countries: Winners and losers / Michel Beine, Fréderic Docquier and Hillel Rapoport // Economic Journal. - 2008. - Iss. 118. - P. 631-652 (in English).

7. Brown W. S. Software portatibility / W. S. Brown // Software engineering techniques : Report on a 
conference sponsored by the NATO Science Committee. Rome, Italy, 27th to 31st October 1969 / Editors : J. N. Buxton and B. Randell. - Birmingham : The Kynoch Press, April 1970. - P. 80-84. (in English).

8. Citizens' summary «Higher education in Europe - modernisation agenda» [online] // European Commission. - [2011]. - 2 p. - Available from : http://ec.europa.eu/education/highereducation/doc/cs_en.pdf (in English).

9. Council Directive 2005/71/EC of 12 October 2005 on a specific procedure for admitting third-country nationals for the purposes of scientific // Official Journal of the European Union. - 2005. - Vol. 48. - 3 November. - P. 15-22 (in English).

10. Davis A. Children of bondage : the personality development of Negro youth in the urban South / Allison Davis, John Dollard. - Washington : American Council on Education, 1940. - XXVIII+299 p. (in English).

11. Devine E. T. Report on the desirability of establishing an employment bureau in the city of New York / Edward T. Devine ; Russell Sage Foundation. - New York : Charities Publication Committee, 1909. 238 p. (in English).

12. Dumont J. C. and Lemaitre, G. Counting immigrants and expatriates in OECD countries: a new perspective [online] / Jean-Christophe Dumont, and Georges Lemaître ; OECD, Directorate for Employment Labour and Social Affairs. - [Paris] : OECD, [2005]. - Available from: http://www.oecd.org/migration/mig/33868740.pdf - ([OECD Social Employment and Migration Working Papers, N. 25]) (in English).

13. Eckpunkte einer Didaktik des mobilen Lernens : Operationalisierung im Rahmen eines Schulversuchs [online] / Ben Bachmair, Maren Risch, Katja Friedrich und Katja Mayer // Themenheft Nr. 19: Mobile Learning in Widening Contexts: Concepts and Cases. - 11. März 2011. - 38 p. - Available from : http://www.medienpaed.com/19/bachmair1103.pdf (in German).

14. Educating Children with Physical Disabilities / Z. P. Nkabinde, F. E. Obiakor, M. T. Offor, D. J. Smith // International Encyclopedia of Education. Third Edition / Editors-in-Chief Penelope Peterson, Eva Baker, Barry McGaw. - Oxford : Elsevier - Academic Press, 2010. - Volume 2. - P. 640-645. (in English).

15. Emigration of Scientists from the United Kingdom : Report of a Committee Appointed by the Council of the Royal Society. - London : Royal Society, 1963. - 32 p. (in English).

16. Google books Ngram Viewer [online] / Google. - 2012. - Available from: http://books.google.com/ngrams (in English).

17. Google Project Glass: User-friendly Tool / Editor : Edward R. Miller-Jones. - FastBook Publishing, 2013. - 140 p. (in English).

18. Gordon E. Net Locality: Why Location Matters in a Networked World / Eric Gordon, Adriana de Souza e Silva. - Hoboken : Wiley-Blackwell, 2011. - 200 p. (in English).

19. Green Paper : The European Research Area: New Perspectives [online] / Commission of the European Communities. $\quad-\quad$ Brussels, 2007. $\quad-\quad 23 \quad$ p. $\quad$ - Available from: http://ec.europa.eu/research/era/pdf/era_gp_final_en.pdf (in English).

20. Growth, competitiveness, employment - The challenges and ways forward into the 21 st century (White Paper). Parts A and B. COM (93) 700. - Luxembourg : Office for Official Publications of the European Communities, 1993. - 151 p. - (Bulletin of the European Communities, Supplement 6/93). (in English).

21. Higher Education in Virtual Worlds: Teaching and Learning in Second Life / Edited by Charles Wankel, Jan Kingsley. - Bingley : Emerald Group Publishing, 2009. - 256 p. (in English).

22. Humboldt A. von. Cosmos : A Sketch of a Physical Description of the Universe / Alexander von Humboldt. - Vol. II. - London : Henry G. Bohn, 1849. - 422 p. (in English).

23. Keegan D. The future of learning: From eLearning to mLearning / Desmond Keegan. - Hagen : Fernuniv., GHS, 2002. - 172 S. - (ZIFF Papiere. 119) (in English).

24. Knight J. Crossborder Education: An Analytical Framework for Program and Provider Mobility / Jane Knight // Higher Education: Handbook of Theory and Research. Volume XXI / Edited by John C. Smart. - Dordrecht : Springer, 2006. - P. 345-395 (in English).

25. Knight J. Higher Education Crossing Borders / J. Knight // International Encyclopedia of Education. Third Edition / Editors-in-Chief Penelope Peterson, Eva Baker, Barry McGaw. - Oxford : Elsevier Academic Press, 2010. - Volume 4. - P. 507-513. (in English).

26. Ko E. The Washington Accord on Engineering Curriculum / E. Ko // International Encyclopedia of Education. Third Edition / Editors-in-Chief Penelope Peterson, Eva Baker, Barry McGaw. - Oxford : Elsevier - Academic Press, 2010. - Volume 4. - P. 209-215 (in English).

27. Köhler M. Rapid (Mobile) E-Learning-Content-Development : Konzeption und Entwicklung des RapidE-Learning-Content-Development-Tools "FLOG" (Flash Learning Objects Generator) zur Erstellung und Verwaltung von wiederverwendbaren Lernobjekten für mobile Endgeräte und PCs : Inauguraldissertation zur Erlangung des Doktorgrades der Humanwissenschaftlichen Fakultät der Universität zu Köln nach der Promotionsordnung vom 12.07.2007 / Michael Köhler. - Köln, 2009. - IX+172 S. (in German). 
28. Kuszpa M. Mobile Learning - Modetrend oder wesentlicher Bestandteil lebenslangen Lernens? / Maciej Kuszpa und Ewald Scherm. - Hagen : Fachbereich Wirtschaftswissenschaft der FernUniversität in Hagen, 2005. - 30 S. - (Diskussionsbeitraege / Fachbereich Wirtschaftswissenschaft, FernUniversitaet in Hagen. 380) (in German).

29. Lachtman S. A. Racial Inequality and the Economic Payoffs of Higher Education / S. A. Lachtman // International Encyclopedia of Education. Third Edition / Editors-in-Chief Penelope Peterson, Eva Baker, Barry McGaw. - Oxford : Elsevier - Academic Press, 2010. - Volume 1. - P. 542-546 (in English).

30. MOTILL : Mobile Technologies in Lifelong Learning/Best practices / Edited by M. Arrigo, O. Di Giuseppe, G. Fulantelli, M. Gentile, G. Merlo, L. Seta, D. Taibi. - Palermo : Eurografica s.r.1, [2010]. 63 p. (in English).

31. Obi S. O. Related Services for Children with Special Needs / S. O. Obi // International Encyclopedia of Education. Third Edition / Editors-in-Chief Penelope Peterson, Eva Baker, Barry McGaw. - Oxford : Elsevier - Academic Press, 2010. - Volume 2. - P. 834--839 (in English).

32. Proceedings of the International Congress on Technology and Blindness: Volume III: Panel III, Sound recording and reproduction. Panel IV, Adapted and special purpose devices, $2 \mathrm{~d}$ ed. / Edited by Leslie L. Clark. - New York : American Foundation for the Blind, 1963. - 384 p. (in English).

33. Shah C. Skills Shortages: Concepts, Measurement and Policy Responses / C. Shah and G. Burke // International Encyclopedia of Education. Third Edition / Editors-in-Chief Penelope Peterson, Eva Baker, Barry McGaw. - Oxford : Elsevier - Academic Press, 2010. - Volume 8. - P. 320-327. (in English).

34. Sheller M. Mobility [online] / Mimi Sheller // sociopedia.isa. - 2011. - 12 p. - Available from : http://www.sagepub.net/isa/resources/pdf/Mobility.pdf (in English).

35. Special Features in City School Systems / United States Bureau of Education. - Washington : Govt. Print. Off., 1913. - (Statistics of land-grant colleges and universities, Vol. 3, Issues 31-45) (in English).

36. Study on Mobility Developments in School Education, Vocational Education and Training, Adult Education and Youth Exchanges [online] / European Commission. - June 2012. - 418 p. - Available from : http://ec.europa.eu/education/documents/more-information/mobility-study-report.pdf (in English).

37. The EU and the Bologna Process - shared goals, shared commitments : Supporting growth and jobs - An agenda for the modernisation of Europe's higher education systems / European Commission. Luxembourg : Publications Office of the European Union, 2012. - 32 p. (in English).

38. The genesis and development of mobile learning in Europe / Agnes Kukulska-Hulme, Mike Sharples, Marcelo Milrad, Inmaculada Arnedillo-Sánchez, Giasemi Vavoula // Combining E-Learning and MLearning: New Applications of Blended Educational Resources / Ed. : David Parsons. - Hershey: IGI Global, 2011. - P. 151-177 (in English).

39. The Role of Mobile Learning in Europe Today [online] / José Carvalho, Ignacio Carril, Ana Dias, Zsolt Ispán, Jim Jack, Desmond Keegan, Gabor Kismihók, Nevena Mileva, Morten Flate Paulsen, Torstein Rekkedal, Bernadette Simpson. - 2008. - 306 p. - Available from : http://www.exact.ie/ebook/mobilelearning/The_Role_of_Mobile_learning_in_Europe_Today.pdf (in English).

40. Traxler J. Context in a Wider Context [online] / John Traxler // Themenheft Nr. 19: Mobile Learning in Widening Contexts: Concepts and Cases. - 8. Juli 2011. - 16 p. - Available from : http://www.medienpaed.com/19/traxler1107.pdf (in English).

41. Traxler J. Current State of Mobile Learning / John Traxler // Mobile Learning : Transforming the Delivery of Education and Training / Edited by Mohamed Ally. - Edmonton : Athabasca University Press, 2009. - P. 9-24 (in English).

42. UNESCO policy guidelines for mobile learning [online] / Edited by Rebecca Kraut. - Paris : UNESCO, 2013. - 41, [1] p. - Available from : http://unesdoc.unesco.org/images/0021/002196/219641E.pdf (in English).

43. Urry J. Climate change, travel and complex futures / John Urry // The British Journal of Sociology. 2008. - Volume 59, Issue 2. - P. 261-279 (in English).

44. Urry J. Sociology Beyond Societies: Mobilities for the Twenty-first Century / John Urry. - London : Routledge, 2000. - 255 p. - (International Library of Sociology) (in English).

45. Wende M. van der. Internationalization of Higher Education / M. van der Wende // International Encyclopedia of Education. Third Edition / Editors-in-Chief Penelope Peterson, Eva Baker, Barry McGaw. - Oxford : Elsevier - Academic Press, 2010. - Volume 4. - P. 540-545 (in English).

46. Zare S. Intelligent Mobile Learning Interaction System (IMLIS) : A Personalized Learning System for People with Mental Disabilities : Doctoral Thesis is submitted ... in fulfillment of the degree of Doctor of Engineering / Saeed Zare ; University of Bremen. - Bremen, 2010. - XX+263 p. (in English).

47. Anischenko V. M. Professional mobility / V. M. Anischenko // Encyclopedia of Education / Academy of Pedagogical Sciences of Ukraine ; editor in chief Academician of NAS and APS of Ukraine, Ukraine President APS V. G. Kremen. - K. : Yurinkom Inter, 2008. - P. 725 (in Ukrainian). 
48. Anischenko V. M. Social mobility / V. M. Anischenko // Encyclopedia of Education / Academy of Pedagogical Sciences of Ukraine ; editor in chief Academician of NAS and APS of Ukraine, Ukraine President APS V. G. Kremen. - K. : Yurinkom Inter, 2008. - P. 840 (in Ukrainian).

49. Balykhin M. G. The international education market trends: the example of the European Union and the Russian Federation : diss. ... cand. econ. sciences : 08.00.14 - world economy / Balykhin Michael Grigorievich ; Ministry of Education and Science, the Russian Peoples' Friendship University. - M., 2009. - 174 p. (in Russian).

50. Magna Charta Universitatum [online] - Bologna, 18 september 1988. - Available from: http://www.magna-charta.org/resources/files/the-magna-charta/english (in English).

51. Great Dictionary of the modern Ukrainian language (with ext. and add.) / Head. ed. V. T. Busel. - K. ; Irpin : Perun, 2005. - 1728 p. (in Ukrainian).

52. Hamanyuk V. A. E-learning, M-learning, Blended Learning and distance learning in foreign language educational system in Germany / Vita Hamanyuk // Pedagogy and Psychology of Professional Education. - 2012. - №2. - P. 211-220 (in Ukrainian).

53. Gracheva V. G. Development of the higher pedagogical education in Western Europe at the present stage : diss. ... cand. ped. sciences : 13.00.01 - general pedagogy, history of pedagogy and education / Gracheva Valerya Gennadievna ; Volgograd State Pedagogical University. - Volgograd, 2007. - 186 p. (in Russian).

54. Grigorieva M. A. The activity approach in teaching computer science students using mobile computer systems : abstract of diss. ... cand. ped. sciences : 13.00 .02 - theory and technique of a training and education (computer science) / Grigorieva Marina Alexandrovna. - M., 2011. - 24 p. (in Russian).

55. Dewey J. Democracy and education / John Dewey ; transl. from English. J. Bosak, M. Oliynyk, G. Pekhnyk. - Lviv : Chronicle, 2003. - 294 p. (in Ukrainian).

56. Demyanenko N. M. Trends of goals and profiles diversification in magistracy at the development of global higher education / Natalya Demyanenko // Pedagogical Sciences : collection of papers. Vol. 2 / Poltava V. G. Korolenko National Pedagogical University; head ed. M. Stepanenko. - Poltava, 2010. P. 44-52 (in Ukrainian).

57. Desiatov T. M. Lifelong learning development trends in Eastern Europe (second half of the twentieth century) : abstract of diss. ... dr. ped. sciences : 13.00.01 - general pedagogy and history of pedagogy / Desiatov Timothy Mykhaylovych ; Institute of Pedagogy of the Academy of Pedagogical Sciences of Ukraine. - K., 2006. - 35 p. (in Ukrainian).

58. Dudar Z. V. Models and methods of mobile distance learning / Z. V. Dudar, D. N. Kolesnik // Eastern European Journal of advanced technologies. - 2008. - № 3/2 (33) - P. 51-54 (in Russian).

59. Zhukov O. V. Application of computer-mobile system in the preparation of vocational training teachers : abstract of diss. ... cand. ped. sciences : 13.00.08 - theory and methods of vocational training / Oleg Viktorovich Zhukov. - M., 2008. - 20 p. (in Russian).

60. Zaskalyeta S. G. Modernization of agricultural vocational training in the EU / Svetlana Zaskalyeta // Comparative educational studies. - 2011. - №2 (8). - P. 42-47 (in Ukrainian).

61. Ivanova V. I. Unified educational space as a factor of innovation development of the European Union economy : abstract of diss. ... cand. econ. sciences : 08.00.14 - world economy / Ivanova Valeriya Ivanovna ; State University of Management. - M., 2012. - 24 p. (in Russian).

62. Kaluga T. A. Mobile learning in distance education / T. A. Kaluga // Bulletin of Luhansk Taras Shevchenko National University. - 2011. - № 12 (223), June. - Part I. - P. 113-124 (in Russian).

63. Kashlacheva T. S. Integration of European and Russian higher education: the institutional aspect : abstract of diss. ... cand. sociol. sciences : 22.00 .04 - social structure, social institutions and processes / Kashlacheva Tatiana Sergeyevna ; St. Petersburg State University. - St. Petersburg, 2007. - 20 p. (in Russian).

64. Kyrda A. G. Trends of education goals at the developed world and Ukraine (the second half of XX century) : abstract of diss. ... cand. ped. sciences : 13.00.01 - general pedagogy and history of pedagogy / Kyrda Alla Grygorivna ; Taras Shevchenko National University of Kyiv. - K., 2005. - 26 p. (in Ukrainian).

65. Kozak T. M. Organizational and pedagogical principles of credit-modular system introduction in training at III-IV accreditation levels higher educational institutions : abstract of diss. ... cand. ped. sciences : 13.00.01 - general pedagogy and history of pedagogy / Tatyana Mihailivna Kozak ; Zhytomyr Ivan Franko State University. - Zhytomyr, 2007. - 19 p. (in Ukrainian).

66. Kozyar M. M. Application of gadgets and widgets technology in teaching / M. M. Kozyar, A. D. Kuzyk // Bulletin of the Lviv State University of Life Safety: collection of scientific papers. - Lviv, 2008. - № 2. P. 7-15 (in Ukrainian).

67. Computer Technology of Learning : reference dictionary / Edited by Gritsenko V. I., Dovgyallo A. M., Saveliev A. Y. - K. : Naukova Dumka, 1992. - 650 p. (in Russian). 
68. Korsak K. V. Socio-philosophical analysis of triad "man-society-education" trends at the beginning of the XXI century : diss. ... dr. philos. sciences : 09.00.10 - philosophy of education / Korsak Konstantin Vitaliyovych ; Academy of Pedagogical Sciences of Ukraine, Institute of Higher Education. - K., 2006. 461 p. (in Ukrainian).

69. Kryazhev P. V. Trends of reforming higher education in Western Europe : abstract of diss. ... cand. ped. sciences : 13.00.01 - general pedagogy and history of pedagogy / Kryazhev Pavlo Vladymyrovych ; Institute of Higher Education of the Academy of Pedagogical Sciences of Ukraine. - K., 2007. - 20 p. (in Ukrainian).

70. Kuvshinov S. V. M-learning - a new reality of education / S. Kuvshinov // Higher education in Russia. 2007. - № 8. - P. 75-78 (in Russian).

71. Kugel S. A. Sociologist notes / S. A. Kugel. - SPb. : Nestor-History, 2005. - 204 p. (in Russian).

72. Kudrya M. M. Processes and trends of higher education in Europe by the end of the 90's and stages of Bologna Process prehistory / Mykola Kudrya // Humanitarian Bulletin of SHEI "Perejaslav-Khmelnytsky State Pedagogical University" : scientific-theoretical collection. Pedagogy. Psychology. Philosophy. 2008 - Vol. 16. - P. 115-120 (in Ukrainian).

73. Kuklev V. A. Formation of mobile learning in open and distance education : diss. ... dr. ped. sciences : 13.00.01 - general pedagogy, history of pedagogy / Kuklev Valeriy Aleksandrovich ; Ulyanovsk State Technical University. - Ulyanovsk, 2010. - 515 p. (in Russian).

74. Distance learning course "The uncertainty of the measurement result" using mobile technology / V. D. Tsidelko, N. A. Yaremchuk, M. V. Galiovskaya, V. V. Babin // Information processing systems. Issue 4 (71). - 2008. - P. 148-150 (in Russian).

75. Lavrychenko N. M. Europe of education and comparative pedagogy in their mutual progress / Natalia Lavrychenko // Comparative educational studies. - 2009. - №1. - P. 10-17 (in Ukrainian).

76. Lazareva L. A. Problems of formation of a common European Higher Education Area (second half of the XX century - the beginning of XXI century) : diss. ... cand. hist. sciences : 07.00 .03 - world history / Lazarev Liliya Aleksandrovna ; Rostov State University. - Rostov-na-Donu, 2006. - 242 p. (in Russian).

77. Lokshyna O. I. Trend as a category of comparative pedagogy / Olena Lokshyna // Comparative educational studies. - 2011. - №2 (8). - P. 5-14 (in Ukrainian).

78. Lubina E. Mobile learning in the high school didactics / Eva Lubina // Bulletin of the Lviv University. Educational Series. - Lviv, 2009. - Vol. 25. - Part 2. - P. 61--66 (in Ukrainian).

79. Lubchenco V. V. Method of educational trajectories construction in mobile training / V. V. Lubchenco, O. S. Shynkaryuk // Bulletin of the National Technical University "Kharkiv Polytechnic Institute" : collection of scientific papers. Special Issue : Information and simulation. - 2011. - №17. - P. 81-85 (in Ukrainian).

80. Maklakova E. V. Historical and pedagogical approaches to evaluating the effectiveness of the educational process at the Western Europe universities : abstract of diss. ... dr. ped. sciences : 13.00 .01 - general pedagogy and history of pedagogy / Maklakova Elena Vladimirovna ; Institute of content and teaching methods of the Russian Academy of Education. - M., 2009. - 35 p. (in Russian).

81. Martynova O. V. Teacher training in Germany while creating a European Higher Education Area : diss. ... cand. ped. sciences : 13.00.01 - general pedagogy, history of pedagogy and education / Martynova Olga Vladimirovna ; V. G. Belinsky Penza State Pedagogical University. - Penza, 2006. - 180 p. (in Russian).

82. Mikhalkina E. G. Computer-mobile technology as a tool of improving the quality of the future managers training : diss. ... cand. ped. sciences : 13.00 .08 - theory and methods of vocational training / Mikhalkina Eugene Germanovna ; Ministry of Education and Science, Moscow State Industrial University. - M., 2009. - 245 p. (in Russian).

83. Motin M. M. Classification of mobile learning systems / M. M. Motin // East European Journal of advanced technologies. - Kharkov : Technology Centre, 2011. - №1 / 2 (49). - P. 30-33 (in Ukrainian).

84. Moshlyak G. A. Historical experience of implementing guidelines for cooperation between Russia and the European countries in the field of higher education at 1999-2009 : abstract of diss. ... cand. ped. sciences : 07.00.02 - native history / Moshlyak Gabriel Alekseyevna ; Russian University of Peoples' Friendship. M., 2012. - 28 p. (in Russian).

85. Negrebetskaya N. V. Basic trends of higher pedagogical education development in Western Europe at the late 20th century (on the basis of Britain, France, Germany) : diss. ... cand. ped. sciences : 13.00 .08 theory and methods of vocational training / Negrebetskaya Natalia Victorovna ; Belgorod State University. - Belgorod, 2003. - 150 p. (in Russian).

86. Nemets L. N. Sustainable development: social and geographical aspects (example of Ukraine) : monograph / Ludmila Nikolayevna Nemets. - Kharkov : Fact, 2003. - 383 p. (in Russian).

87. Onishchenko L. V. Higher Technical School of France in the context of common European educational area building : abstract of diss. ... cand. ped. sciences : 13.00.01 - general pedagogy, history of pedagogy / Onishchenko Lilia Valentinovna ; Institute of Pedagogy and Psychology of Professional Education of 
the Russian Academy of Education. - Kazan, 2011. - 22 p. (in Russian).

88. Osadchiy V. V. Theory and practice of mobile learning technology usage in pedagogical university / V. V. Osadchiy // Teaching Discourse : collection of scientific papers / Institute of Pedagogy of the Academy of Pedagogical Sciences of Ukraine, Khmelnytsky Humanitarian and Pedagogic Academy. Khmelnitsky, 2011. - Issue 9. - P. 258-263. (in Ukrainian).

89. Poberezska A. G. Trends in Higher Education in Western Europe and Ukraine : abstract of diss. ... cand. ped. sciences : 13.00 .01 - general pedagogy and history of pedagogy / Poberezska Anna Georgievna ; Institute of Higher Education of the Academy of Pedagogical Sciences of Ukraine. - K., 2005. - 22 p. (in Ukrainian).

90. Pozhyvilova O. V. Development of scientific and pedagogical staff training in the European region and Ukraine (1990-2005) : diss. ... cand. ped. sciences : 13.00.01 - general pedagogy and history of pedagogy / Pozhyvilova Olena Volodymyrivna ; Institute of Higher Education of the Academy of Pedagogical Sciences of Ukraine. - K., 2006. - 181 p. (in Ukrainian).

91. Polunina L. N. Teacher training in European countries: national priorities and integration in the context of the Bologna process : diss. ... cand. ped. sciences : 13.00.01 - general pedagogy, history of pedagogy / Polunina Ludmila Nikolayevna ; Federal Agency for Education, Tula State Lev Tolstoy Pedagogical University. - Tula, 2006. - 202 p. (in Russian).

92. Postova L. S. New trends in higher education at the European context / Postova L. S. // Proceedings. Pedagogy. Volume VII. - [Mykolaiv], 2000. - P. 49-50 (in Ukrainian).

93. About the National Strategy for the Development of Education in Ukraine for the period till 2021 : Decree № 344/2013 from 06.25.2013 [online] / President of Ukraine. - Available from: http://www.president.gov.ua/documents/15828.html (in Ukrainian).

94. Rashevska N. V. Technological conditions for the implementation of mobile learning in higher education / N. V. Rashevska // Bulletin of Cherkassy University. - Cherkasy, 2011. - Issue 201. - Part I. - P. 100104 (in Ukrainian).

95. Rizhova N. A. Integration of the Russian library and information education in the Bologna process: substantive and organizational aspects : diss. ... cand. ped. sciences : 05.25 .03 - library science and bibliology / Natalia Anatolevna Rizhova ; FSEIHPE "Orel State institute of arts and culture". - Orel, 2008. - 236 p. (in Russian).

96. Sbruyeva A. A. Global and regional trends of higher education in building knowledge societies : preprint / A. A. Sbruyeva. - Sumy : Makarenko SumSPU, 2008. - 80 p. (in Ukrainian).

97. Semerikov S. O. Mobile learning: history, theory, methods / S. Semerikov, I. Teplickiy, S. Shokalyuk // Informatics and Information Technology in educational institution. - 2008. - №6. - P. $72-82$; 2009 . №1. - P. 96-104 (in Ukrainian).

98. Semerikov S. O. Foundation of study informatic subjects in high school: monograph / Semerikov S. O. ; scientific editor academician of the Academy of Pedagogical Sciences of Ukraine, doctor. ped. s., prof. M. I. Zhaldak. - Krivoy Rog : Mineral ; K. : National Pedagogical Dragomanov University, 2009. - 340 p. (in Ukrainian).

99. Slovak K. I. Methods of use of mathematical mobile environments in learning higher mathematics students of economic specialties : diss. ... cand. ped. sciences : 13.00 .10 - information and communication technologies in education / Slovak Katerina Ivanivna ; Institute of Information Technologies and Learning National Academy of Pedagogical Sciences of Ukraine. - 291 p. (in Ukrainian).

100. Stryuk M. I. Learning object as component of a mobile learning / M. I. Stryuk, A. M. Stryuk // Scientific Papers Kamenetz-Podolsk National University. An educational series / [ed. : P. S. Atamanchuk (head, scientific ed.) et al.]. - Kamenets-Podolsk : Ivan Ogienko Kamenets-Podolsk National University, 2012. Vol. 18: Innovation in teaching physics: national and international experience. - P. 83-86. (in Ukrainian).

101. Sushentseva L. L. Formation of professional mobility of future skilled workers in vocational education institutions: theory and practice : monograph / Lily Leonidivna Sushentseva ; Ed. N. G. Nychkalo ; Institute of Vocational Education NAPS of Ukraine. - Krivoy Rog : Publishing House, 2011. - 439 p. (in Ukrainian).

102. Teplitsky I. O. The model of mobile learning in middle and high school / I. O. Teplitsky, S. O. Semerikov, A. P. Polishchuk // Computer simulation in education : materials of III Ukrainian scientific-methodical seminar. - Krivoy Rog, April 24, 2008 - Krivoy Rog : KSPU, 2008. - P. 45-46 (in Ukrainian).

103. Trius Yu. V. Innovative information technologies in teaching mathematical disciplines / Yu. V. Trius // Proceedings of the National University "Lviv Polytechnic". Series: Informatization of higher education / Ministry of Education, Youth and Sports of Ukraine, National University "Lviv Polytechnic". - Lviv : Lviv Polytechnic publishing house, 2012. - №731. - P. 76-81 (in Ukrainian).

104. Tryapitsyn A. V. Simulation of school administrators training in the context of the European educational 
process : diss. ... dr. ped. sciences : 13.00 .08 - theory and a vocational training / Tryapitsyn Alexandr Vyacheslavovich ; St. Petersburg Academy of Postgraduate Pedagogical Education. - St. Petersburg, 2005. - 479 p. (in Russian).

105. Tysiachniouk M. S. John Urry mobile sociology / M. S. Tysiachniouk // Journal of Sociology and Social Anthropology. - 2004. - Volume VII. - №4. - P. 200-208 (in Russian).

106. Filatova N. S. Philosophical foundations of the educational area model: Bologna scenario : abstract of diss. ... cand. philos. sciences : 09.00.11 - social philosophy / Filatova Natalya Stepanovna ; I. Ulyanov Chuvash State University. - Cheboksary, 2007. - 22 p. (in Russian).

107. Khomenko L. G. History of Native Cybernetics and Informatics : monograph / Khomenko L. G. - K. : V. M. Glushkov Institute of Cybernetics of National Academy of Sciences of Ukraine, 1998. - 455 p. (in Russian).

108. Chistokhvalov V. N. Formation and implementation of the integrational educational processes in the Russian Federation and the European Union in 1991--2005: a comparative analysis of the experience, problems and prospects : abstract of diss. ... dr. hist. sciences : 07.00 .02 - native history / Chistokhvalov Viktor Nikolaevich ; Russian University of Peoples' Friendship. - M., 2010. - 51 p. (in Russian).

109. Shunevych B. I. Development of distance learning in higher education in Europe and North America : abstract of diss. ... dr. ped. sciences : 13.00.01 - general pedagogy and history of pedagogy / Shunevych Bogdan Ivanovich ; Institute of Higher Education of the Academy of Pedagogical Sciences of Ukraine. K., 2008. - 36 p. (in Ukrainian).

\section{$($ (c) $)$ BY-NC-SA}

This work is licensed under Creative Commons Attribution-NonCommercial-ShareAlike 4.0 International License. 